\title{
Geochemical focusing and sequestration of manganese during eutrophication of Lake Stechlin (NE Germany)
}

\author{
Grzegorz Scholtysik (D) Olaf Dellwig (D) Patricia Roeser (D) Helge Wolfgang Arz (D) \\ Peter Casper (iD) C Christiane Herzog • Tobias Goldhammer (i) Michael Hupfer
}

Received: 3 April 2020/Revised: 4 November 2020/Accepted: 11 November 2020/Published online: 24 November 2020

(C) The Author(s) 2020

\begin{abstract}
Significant sedimentation of manganese $(\mathrm{Mn})$ in form of manganese oxides $\left(\mathrm{MnO}_{\mathrm{x}}\right)$ and the subsequent formation of authigenic calcium-rich rhodochrosite $\left(\mathrm{Mn}(\mathrm{Ca}) \mathrm{CO}_{3}\right)$ were observed in the seasonally stratified hard water Lake Stechlin in northeastern Germany. This manganese enrichment was assumed to be associated with recent eutrophication of the formerly oligotrophic lake. The mechanisms and processes involved were examined by analysing: (i) short sediment cores obtained from seven locations
\end{abstract}

Responsible Editor: Feng Zhou.

Electronic supplementary material The online version contains supplementary material available at https://doi.org/10. 1007/s10533-020-00729-9.

G. Scholtysik $(\bowtie) \cdot$ C. Herzog · T. Goldhammer .

M. Hupfer

Department of Chemical Analytics and Biogeochemistry, Leibniz Institute of Freshwater Ecology and Inland Fisheries (IGB), Müggelseedamm 301, 12587 Berlin, Germany

e-mail: scholtysik@igb-berlin.de

O. Dellwig · P. Roeser $\cdot$ H. W. Arz

Department of Marine Geology, Leibniz Institute for Baltic Sea Research Warnemünde (IOW), Seestrasse 15, 18119 Rostock, Germany

P. Casper

Department Experimental Limnology, Leibniz Institute of Freshwater Ecology and Inland Fisheries (IGB), Alte Fischerhütte, 216775 Stechlin, Germany along a depth transect ranging from $69.5 \mathrm{~m}$ (the deepest point) to $38 \mathrm{~m}$; (ii) sediment traps located at $20 \mathrm{~m}$ and $60 \mathrm{~m}$ water depths; (iii) water column profiles; and (iv) porewater profiles at $69.5 \mathrm{~m}$ and $58 \mathrm{~m}$ depths. Sedimentary Mn enrichment was observed at water depths below $56 \mathrm{~m}$ and increased to more than $25 \mathrm{wt} \%$ at the deepest site. Between 2010 and 2017, Mn accumulation at the deepest site was $815 \mathrm{~g} \mathrm{Mn} \mathrm{m}^{-2}$. Transfer of Mn from the shallower towards the deepest parts of the lake was initiated by reductive dissolution of $\mathrm{MnO}_{\mathrm{x}}$ and diffusion of dissolved $\mathrm{Mn}$ from the sediment to the overlying water column. Manganese was then dissipated via turbulent mixing and subsequently oxidised to $\mathrm{MnO}_{\mathrm{x}}$ before being transported towards the deepest zone. Transformation of the redeposited $\mathrm{MnO}_{\mathrm{x}}$ to $\mathrm{Mn}(\mathrm{Ca}) \mathrm{CO}_{3}$ favoured the final burial of $\mathrm{Mn}$. We show that eutrophication and the areal spreading of anoxic conditions may intensify diagenetic processes and cause the spatial redistribution of $\mathrm{Mn}$ as well as its effective burial. Contrary to many previous findings, we show that increases of $\mathrm{Mn}$ and $\mathrm{Mn} / \mathrm{Fe}$ can also be used as indicators for increasing anoxic conditions in previously oligotrophic lakes.

Keywords Lacustrine sediments - Geochemical focusing · Eutrophication - Diagenesis . Rhodochrosite $\cdot$ Varves 


\section{Introduction}

Manganese (Mn) is a redox-sensitive element and an important terminal electron acceptor in the anaerobic mineralisation of organic matter in aquatic ecosystems. At the oxic-anoxic transition zone, i.e., at the sediment-water interface (SWI) or in the water column of stratified water bodies, it typically circulates between the dissolved phase $\left(\mathrm{Mn}_{\text {diss }}\right)$ in the underlying reducing environment and the solid phase in the overlying oxic environment (e.g. Calvert and Pedersen 1993; Davison 1993; Tribovillard et al. 2006). The predominant reduced form of this metal found in nature is $\mathrm{Mn}^{2+}$, whereas $\mathrm{Mn}^{3+}$ is found as an important intermediate form in various suboxic and oxic waters (Trouwborst et al. 2006; Dellwig et al. 2012; Madison et al. 2013; Oldham et al. 2017). In its particulate phase, Mn forms oxide (oxidation state (IV), carbonate (II), or sulphide (II) mineral phases (Suess 1979; Davison 1993; Dellwig et al. 2010; Häusler et al. 2018).

Depending on the morphological and hydrophysical characteristics of lakes and marine basins, redox changes may cause a spatial redistribution of particulate Mn in lakes (Delfino et al. 1969; Ostendorp and Frevert 1979; Schaller and Wehrli 1996; Dellwig et al. 2018) and marine basins (Rajendran et al. 1992; Lenz et al. 2015a, b; Häusler et al. 2018; Schaller and Wehrli 1996) introduced the term "geochemical focusing" to address the mobilisation of $\mathrm{Mn}$ from shallow sediments, its transportation within the water column, and sedimentation in the deep zones of lakes. In marine geology and sedimentology, the term "shelf-to-basin shuttle" is more common for this transport process (Lyons and Severmann 2006; Scholz et al. 2013).

While geochemical focusing describes the phenomenon of spatial $\mathrm{Mn}$ redistribution, it does not imply a long-term burial of Mn. Effective burial may occur if, for example, $\mathrm{Mn}$ is rapidly buried due to high Mn sedimentation rates in combination with low $\mathrm{Mn}$ oxide $\left(\mathrm{MnO}_{\mathrm{x}}\right)$ reduction rates (Granina et al. 2004; Och et al. 2012). Alternatively, a mineral phase that is resistant to reductive dissolution within sediments may form (Hamilton-Taylor and Price 1983; Stauffer 1987; Giblin 2009). Such mineral may be calcium (Ca)-rich rhodochrosite (here referred to as $\left.\mathrm{Mn}(\mathrm{Ca}) \mathrm{CO}_{3}\right)$ that has been reported in lacustrine (Mayer et al. 1982; Nuhfer et al. 1993; Friedl et al.
1997; Roeser et al. 2016; Dräger et al. 2017) and marine sediments (Suess 1979; Calvert and Pedersen 1996; Neumann et al. 2002; Johnson et al. 2016; Dellwig et al. 2018; Häusler et al. 2018).

The formation of $\mathrm{Mn}(\mathrm{Ca}) \mathrm{CO}_{3}$ is fairly well-studied in anoxic basins of the Baltic Sea and has been associated with inflow events from the North Sea that oxidise formerly sulphidic waters highly enriched in $\mathrm{Mn}_{\text {diss }}$, which ultimately results in significant deposition of $\mathrm{MnO}_{\mathrm{x}}$ on the seafloor (e.g. Huckriede and Meischner 1996). When reducing conditions are reestablished and cause substantial $\mathrm{MnO}_{\mathrm{x}}$ dissolution, $\mathrm{Mn}(\mathrm{Ca}) \mathrm{CO}_{3}$ formation may occur close to the surface of sediments where $\mathrm{Mn}_{\text {diss }}$ concentrations reach supersaturation (Middelburg et al. 1987; Calvert and Pedersen 1993) although involvement of bacteria has also been suggested (Aller and Rude 1988; Burdige 1993; Yao and Millero 1993; Neumann et al. 2002; Lee et al. 2011; Henkel et al. 2019). The long-term oxygenation of bottom waters in contact with anoxic sediment was found to facilitate the formation of $\mathrm{Mn}(\mathrm{Ca}) \mathrm{CO}_{3}$ in the Baltic Sea (Dellwig et al. 2018; Häusler et al. 2018). Alternative models of $\mathrm{Mn}(\mathrm{Ca}) \mathrm{CO}_{3}$ formation were presented by Herndon et al. (2018) and Wittkop et al. (2020), where the formation of Mn-rich calcite and rhodochrosite was suggested to occur also within redox-stratified water bodies of Fayetteville Green Lake and Brownie Lake supported by calcite presence.

The concept of geochemical focusing is still not well understood and suffers from a substantial lack of in-situ documentation. Many studies of the phenomenon focussed on the marine environment (e.g. Lyons and Severmann 2006; Scholz et al. 2013; Lenz et al. 2015a, b; Häusler et al. 2018), while lacustrine studies are notably rare (Schaller and Wehrli 1996; Naeher et al. 2013). The diagenesis of $\mathrm{Mn}$ and the resulting role of $\mathrm{Mn}$ as a proxy of changing redox conditions is similarly poorly understood.

Exceptionally high Mn contents were found in the surface sediments of the seasonally stratified Lake Stechlin in Germany (Kleeberg 2014). However, this could not be simply explained by marine models developed for temporarily stratified basins because the waters of Lake Stechlin are mostly oxic-suboxic due to the annual mixing of the waterbody. Furthermore, the suggestion by Mackereth (1966) and Wersin et al. (1991) that Mn should be increasingly depleted from 
sediments upon exposure to more reducing conditions could not explain the Mn enrichment of Lake Stechlin.

To address these knowledge gaps, we aimed to explain the recent accumulation of $\mathrm{Mn}$ in the deepest areas of Lake Stechlin and describe the pathways of geochemical focusing. We hypothesised that recent eutrophication and lowered hypolimnetic $\mathrm{O}_{2}$ concentrations have influenced the lake's internal Mn cycle. Based on the quantitative analysis of Mn pools and fluxes using sediment core sampling from various water depths, highly resolved measurements at the SWI, sediment trap sampling at two different water depths, and monitoring of $\mathrm{Mn}_{\text {diss }}$ in the water column, we develop a new conceptual model to describe the observed phenomenon.

\section{Study site}

Lake Stechlin is located in north-eastern Germany $\left(53^{\circ} 09^{\prime} \mathrm{N}, 13^{\circ} 02^{\prime} \mathrm{E}\right.$, Fig. 1) in a sandy glacial landscape with a catchment area covered in $80 \%$ by forest. The dimictic lake is characterised by an area of $4.23 \mathrm{~km}^{2}$, a mean depth of $23.3 \mathrm{~m}$, a maximum depth of $69.5 \mathrm{~m}$ (Koschel and Adams 2003), and is thermally stratified from about April until the end of December. Except for two narrow and shallow channels that connect to Lake Nehmitz in the southwest, Lake Stechlin lacks substantial surface in- or outflows. The water level is nearly constant since 1957 as the lake outlet is regulated (Pöschke et al. 2018). The major sources of water are precipitation and groundwater (Richter and Koschel 1985). During the operation of a nuclear power plant between 1966 and 1990, 300,000 $\mathrm{m}^{3}$ day $^{-1}$ water from the neighbouring Lake Nehmitz was used for cooling and was discharged into Lake Stechlin heated by $10{ }^{\circ} \mathrm{C}$. The water residence time during that time was 335 days and since 1990 it increased to $>40$ years (Koschel and Adams 2003). Thermal pollution from the nuclear power plant, and more recently climate change, have increased the duration of the summer stratification period in the lake (Kirillin et al. 2013). Long-term monitoring data of the Leibniz Institute of Freshwater Ecology and Inland Fisheries (IGB) showed that the lake annual average total phosphorus concentration has increased from $14 \pm 3$ (2000-2010) to $33 \pm 3 \mu \mathrm{g} \mathrm{L}^{-1}$ (2015-2017). The annual mean chlorophyll- $a$ concentration in the surface waters for the period from April to October also consistently increased from $2.6 \pm 0.6(2000-2010) \quad$ to $\quad 3.3 \pm 0.4 \mu \mathrm{g} \quad \mathrm{L}^{-1}$ (2015-2017). Minimal $\mathrm{O}_{2}$ concentrations were observed at a water depth below $60 \mathrm{~m}$, which decreased from $4.8 \pm 0.7(2000-2010)$ to $0.7 \pm 0.4 \mathrm{mg} \mathrm{L}^{-1}$ (2015-2017) with major drops in 2003 and 2011. The higher $\mathrm{O}_{2}$ consumption rate has resulted in a steadily increasing area of the lake bottom waters with less than $2 \mathrm{mg} \mathrm{O} \mathrm{L}^{-1}$ at the end of the stratification period. Consequently, Lake Stechlin has lost its oligotrophic status and seems on a trajectory towards more eutrophic conditions. These recent changes in water quality have been described in detail by Selmeczy et al. (2019).

\section{Material and methods}

Sampling and preparation of sediment cores

Eight sediment cores (60 cm length, $6 \mathrm{~cm}$ diameter) were obtained with a Kajak gravity corer (UWITEC, Mondsee, Austria) during two field campaigns: one core was obtained from the deepest part of the lake at a water depth of $69.5 \mathrm{~m}$ on 24 August 2017 and the other six cores (at depths of $65 \mathrm{~m}, 64 \mathrm{~m}, 61 \mathrm{~m}, 56 \mathrm{~m}, 51 \mathrm{~m}$, and $38 \mathrm{~m}$ ) were obtained along a depth-transect towards the south-eastern slope on 3 May 2018 (Fig. 1). After sampling, the taped cores were placed horizontally and split with a stainless-steel plate into two halves. The sediment was stabilised by a floral foam from above so that the sediment remained undisturbed when placed horizontally. One half was used for imaging and X-ray fluorescence (XRF) core scanning, and the second half was sub-sampled into $1 \mathrm{~cm}$ sections. The sediments were freeze-dried, ground with an agate mortar, and used for further geochemical analyses. On 15 November 2017, 12 additional cores were taken at depths of $69.5 \mathrm{~m}$ and $58 \mathrm{~m}$, respectively (Fig. 1). The surface sediments $(0-1 \mathrm{~cm}$ and $1-2 \mathrm{~cm})$ at each depth were pooled and used for the analysis of the Mn fraction by sequential extraction. The total mass accumulation of $\mathrm{Mn}$ in the sediment cores was calculated based on the total $\mathrm{Mn}$ content of their Mn-rich upper layers (defined as samples with $>1.2 \mathrm{wt} \% \mathrm{Mn}$ ) multiplied by dry mass per area of the respective layers. The cores from the deepest part of the lake, which were used for Scanning Electron Microscopy-Energy-Dispersive X-ray 


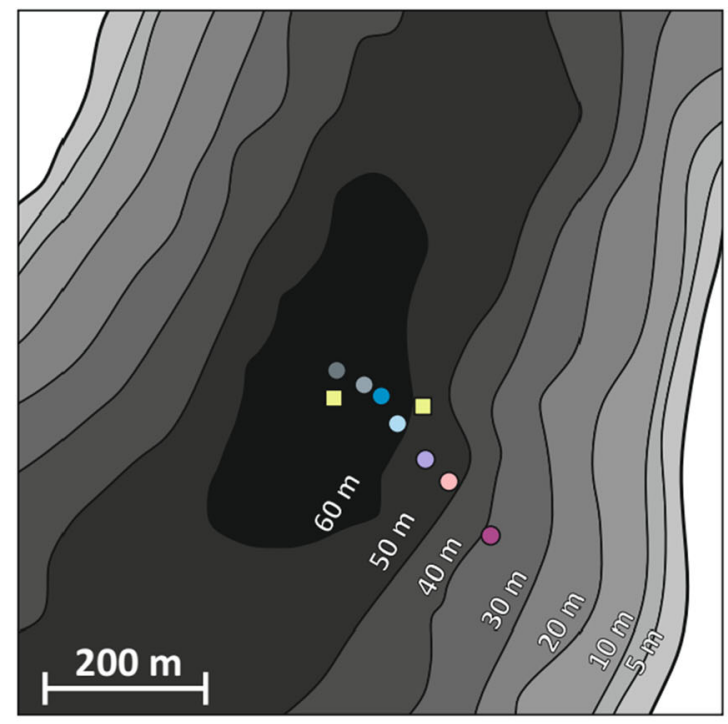

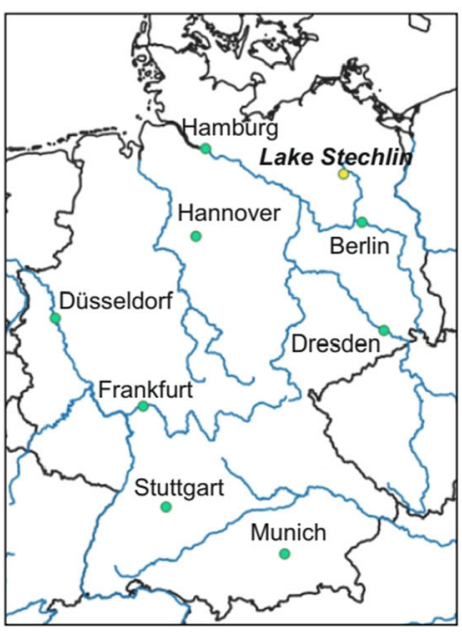

Fig. 1 Location of Lake Stechlin in Germany (lower left), bathymetric map (right), and the position of the sediment sampling sites along a depth transect from $69.5 \mathrm{~m}$ to $38 \mathrm{~m}$ and porewater sampling positions at $69.5 \mathrm{~m}$ and $58 \mathrm{~m}$ (upper left).

Spectroscopy (SEM-EDX) analysis, were obtained on 19 November 2018 and were freeze-dried but not ground.

\section{Sampling of settling seston}

Sediment traps were positioned at depths of $20 \mathrm{~m}$ and $60 \mathrm{~m}$ in the water column above the deepest point of the lake to determine Mn sedimentation rates (Fig. 1). The sediment traps comprised four cylinders $9 \mathrm{~cm}$ in diameter and $100 \mathrm{~cm}$ in height. The traps were treated with $0.13 \%$ formaldehyde to avoid microbial
STE-69.5 m (+ position of the sediment traps)

O STE-65 $\mathrm{m}$

O STE-64 m

O STE-61 m

O STE-56 $\mathrm{m}$

O STE- $51 \mathrm{~m}$

O STE-38 m

$\square$ Pore water „peeper“

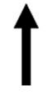

$\mathrm{N}$ 
were filled using linearly interpolated values, but the longest gap in the record (between 2013 and mid2016) was not interpolated. To illustrate the formation of authigentic $\mathrm{Mn}$ minerals (e.g., $\mathrm{MnO}_{\mathrm{x}}$ formed at the redoxcline), the Mn contents in the sediment traps were related to aluminium ( $\mathrm{Al}$ ) as representative of the lithogenic background sedimentation.

\section{Water and porewater sampling}

Water samples were collected every month from August 2017 until January 2019, except February and March 2018, at several water depths depending on the mixing regime: a surface water sample and every $5 \mathrm{~m}$ below $30 \mathrm{~m}$ during the stagnation period, and a surface water sample, $40 \mathrm{~m}, 60 \mathrm{~m}, 65 \mathrm{~m}$ and $68 \mathrm{~m}$ during the mixing period. All water samples were taken at the deepest site of the lake using a water sampler (Limnos, Turku, Finland). Dissolved manganese $\left(\mathrm{Mn}_{\text {diss }}\right)$ concentrations were determined by ICP-OES (iCAP 6300, Thermo Fischer Scientific, Waltham, USA) after membrane filtration of water samples using a 0.45 $\mu \mathrm{m}$ cellulose acetate syringe filter (Whatman $\mathrm{GmbH}$, Dassel, Germany) and fixing with $10 \mu \mathrm{L}$ of $2 \mathrm{M} \mathrm{HCl}$ per $1 \mathrm{~mL}$ of sample. The mass of $\mathrm{Mn}_{\text {diss }}$ in the water column at the deepest point $\left(\mathrm{g} \mathrm{m}^{-2}\right)$ was calculated by the depth-weighted mean value multiplied by a water depth of $69 \mathrm{~m}$ (see also supplementary dataset). Oxygen concentrations were determined by $\mathrm{O}_{2}$ logger (YSI 6600 V2-4 Xylem Analytics; Rye Brook, USA).

Porewater profiles were obtained using dialysis chambers $(30 \times 3.2 \times 1.5 \mathrm{~cm})$ consisting of acrylic glass covered with a HT-Tuffryn 200 membrane (GELMAN) following the method of Hesslein (1976). A frame was used to keep the dialysis chamber in the vertical position within the sediments. The dialysis chambers were filled with deionised water, deoxygenated using $\mathrm{N}_{2}$, and placed in the sediments at water depths of $69.5 \mathrm{~m}$ and $58 \mathrm{~m}$ (Fig. 1). After 14 days of exposure, the dialysis chambers were retrieved on 29 November 2017 and 26 June 2018, and the collected porewater was acidified with $10 \mu \mathrm{L}$ of $2 \mathrm{M} \mathrm{HCl}$ per $1 \mathrm{~mL}$ of sample. Porewater profiles for sulphate and sulphide were obtained using an analogous dialysis chamber at the deepest site $(69.5 \mathrm{~m})$ on 19 November 2018. Dissolved sulphide was fixed with a $0.2 \mathrm{~mL}$ $\mathrm{ZnAc}$ solution (about $50 \mathrm{mM} \mathrm{L}^{-1} \mathrm{Zn}$ ) per $2 \mathrm{~mL}$ sample.
Geochemical analyses

\section{$X R F$ core scanning}

The sediment cores were scanned for $\mathrm{Mn}, \mathrm{Ca}$, titanium (Ti), and silicon ( $\mathrm{Si}$ ) using an ITRAX core scanner (Cox, Mölndal, Sweden; Croudace et al. 2006; Jarvis et al. 2015) at the Leibniz Institute of Baltic Sea Research Warnemünde (IOW). Core halves were scanned using a Cr-tube set to $30 \mathrm{kV}, 30 \mathrm{~mA}$, and with an exposure time of $15 \mathrm{~s}$ per step. The measurement resolution in the core from 69.5 to $0.05 \mathrm{~mm}$ for the uppermost $7 \mathrm{~cm}$ (varved/laminated section) and $0.2 \mathrm{~mm}$ for the lower homogenous section; the other sections of the cores were measured using a $0.1 \mathrm{~mm}$ resolution. The range of the resulting XRF signal was 3500-170,000 cps for Mn; 2000-80,000 cps for Ca; 130-1800 cps for Ti; and 75-1200 cps for Si. X-ray images were also obtained with the ITRAX core scanner at a $0.2 \mathrm{~mm}$ downcore resolution.

\section{Dissolved and solid elemental and compound analysis}

The $\mathrm{Mn}, \mathrm{Ca}, \mathrm{Al}$, and $\mathrm{Fe}$ content of the $69.5 \mathrm{~m}$ depth core was determined using inductively coupled plasma-optical emission spectrometry (ICP-OES; iCAP 7400 Duo, Thermo Fisher Scientific, Waltham, USA) after acid digestion $\left(\mathrm{HNO}_{3}, \mathrm{HClO}_{4}\right.$, and $\left.\mathrm{HF}\right)$ following the procedure after Dellwig et al. (2019). Precision and trueness were checked by using the international reference material SGR-1b (USGS) and were better than $6 \%$ and $-5 \%$, respectively. The relative content of $\mathrm{Mn}$ and $\mathrm{Ca}$, as determined by the $\mathrm{XRF}$, was linearly calibrated with the absolute content determined by ICP-OES as successfully applied by Moller et al. (2012). Prior calibration using an offsetcorrection of depth based on five prominent peaks in $\mathrm{Ca}$ and $\mathrm{Mn}$ was performed between the halves of the cores used for the XRF and ICP-OES analyses. Then the average XRF values of less resolved ICP-OES intervals were plotted against the ICP-OES measurements, giving linear regressions coefficients of $\mathrm{R}^{2}=0.87$ for $\mathrm{Mn}$ and $\mathrm{R}^{2}=0.96$ for $\mathrm{Ca}$. The sediment trap material was digested by a mixture of $36 \% \mathrm{HCl}$ and $65 \% \mathrm{HNO}_{3}$ at a volumetric ratio of 1:3 (aqua regia) in a high-pressure microwave (MLS GmbH, Leutkirch, Germany). The Mn and $\mathrm{Al}$ contents in the digested trap material, in the core from $38 \mathrm{~m}$ water depth, and dissolved $\mathrm{Mn}$ and $\mathrm{Ca}$ in the water samples 
(lake and porewater) were measured using ICP-OES (iCAP 6300 Duo, Thermo Fisher Scientific). The corresponding precision and accuracy were $<9 \%$ and $<5 \%$, respectively. The $\mathrm{pH}$ of the porewaters was determined using a SenTix ${ }^{\circledR} 940$ electrode (WTW 3430, Weilheim, Germany). Dissolved sulphide concentrations were measured using the method after Cline (1969) and the precision of this method is usually around 3\% (Dellwig et al. 2019). Sulphate concentrations were determined via ion chromatography (Shimadzu, Kyoto, Japan) and the relative standard error was $<1 \%$. The contents of total carbon (TC) and total organic carbon (TOC), the latter after treatment with $1 \mathrm{M} \mathrm{HCl}$ in order to remove carbonates, were determined using a CNS element analyser (Vario EL, Elementar Analysensysteme GmbH, Langenselbold, Germany). Total inorganic carbon (TIC) was calculated as the difference between TC and TOC. Each sample of the CNS analysis was performed as duplicate and the relative standard error was $<1 \%$ for $\mathrm{TC}$ and $<4 \%$ for TOC. Loss on ignition (LOI) for the flux calculations was determined as the loss of weight after the combustion of dried sediment at $450{ }^{\circ} \mathrm{C}$ for $3 \mathrm{~h}$, and the relative standard error $(\mathrm{n}=2)$ was $<1 \%$.

\section{Manganese fractionation}

To distinguish reducible $\mathrm{MnO}_{\mathrm{x}}$ from acid-soluble $\mathrm{Mn}$ carbonates from the sediment trap material from $60 \mathrm{~m}$ (exposure time: 19 September-29 October 2018, and 29 October-18 December 2018) and surface sediments $(0-1$ and $1-2 \mathrm{~cm}, 69.5 \mathrm{~m}$ and $58 \mathrm{~m}$ water depth), we deployed a sequential wet-chemical extraction protocol that follows the procedure of Psenner et al. (1984) originally developed for phosphorus fractions. The extraction scheme comprised four steps: (1) $1 \mathrm{M}$ ammonium chloride $\left(\mathrm{NH}_{4} \mathrm{Cl}\right)$, representing loosely adsorbed and porewater $\mathrm{Mn}$, (2) $0.11 \mathrm{M}$ bicarbonate-dithionite (BD) solution, for the reductive-soluble fraction representing $\mathrm{MnO}_{\mathrm{x}}$ mineral phases, (3) $1 \mathrm{M}$ sodium hydroxide $(\mathrm{NaOH})$, and (4) $0.5 \mathrm{M}$ hydrochloric acid $(\mathrm{HCl})$ targeting (acid-soluble) carbonate-bound Mn. For testing the plausibility, we compared the total Mn content determined by ICPOES with the sum of the individual fractions. Each sample was performed in duplicate, the results were presented as averages, and the relative standard error was $<5 \%$. The Mn concentrations in extracts 1,2 , and 4 were routinely measured by atomic absorption spectroscopy (AAS; Perkin Elmer 3300, RodgauJuegesheim, Germany). Since Mn was not measured in extract 3, $\mathrm{NaOH}$ soluble $\mathrm{Mn}$ is a part of residual $\mathrm{Mn}$ that was calculated as the difference between the total $\mathrm{Mn}$ and the sum of $\mathrm{Mn}$ in the $\mathrm{NH}_{4} \mathrm{Cl}, \mathrm{BD}$, and $\mathrm{HCl}$ fractions.

\section{SEM-EDX}

Scanning electron microscopy with energy dispersive X-ray fluorescence (SEM-EDX, FESEM Zeiss Merlin VP Compact) served for identification of authigenic mineral phases in the sediment trap material and sediment samples. The solid material was suspended in an ultrasonic bath and filtrated with $0.4-\mu \mathrm{m}$ polycarbonate filters. After drying at $60{ }^{\circ} \mathrm{C}$ for $24 \mathrm{~h}$, the filters were fixed on $\mathrm{Al}$ stubs and carbon-coated. The working distance in the SEM-EDX was $8.5 \mathrm{~mm}$ and spot analysis was done at an accelerating voltage of $15 \mathrm{kV}$ using AZtec Energy software (Oxford Instruments). The identification and determination of relative abundances of the mineral phases were done by automated particle analyses. This procedure includes recognition of particles by grey level thresholds with a minimum ECD of $0.67 \mu \mathrm{m}$ at a magnification of 2000. Identified particles $(\sim 1500$ particles per sample) were measured for their average elemental composition by a secondary electron detector comprising several spot analyses per particle followed by image processing and particle classification using the AZtec Feature software (Oxford Instruments). Peak overlapping (e.g. $\mathrm{Mn} \mathrm{k} \beta$ and $\mathrm{Fe} \mathrm{k} \alpha$ lines at 6.4-6.5 keV) was solved by peak deconvolution. Depending on the chosen instrument parameters, detection limits of the EDX measurements of our environmental samples typically range from 0.1 to 1 wt $\%$ and values $<1 \mathrm{wt} \%$ should be considered as informative only. Based on the chemical composition of the minerals and previous experiences with suspended particulate matter and sediment samples from the Baltic Sea (Dellwig et al. 2010, 2018; Häusler et al. 2018), the threshold values for the identification of the mineral phases were as follows: $\mathrm{Mn}>30 \%, \mathrm{Ca}<$ $6 \%, \mathrm{Fe}<5 \%$, and $\mathrm{P}<5 \%$ for $\mathrm{Mn}$ oxide; $\mathrm{Mn}>$ $30 \%, \mathrm{Ca}>6 \%$, and $\mathrm{Fe}<5 \%$ for Ca-rich $\mathrm{Mn}$ carbonate; and $\mathrm{Mn}>10 \%, \mathrm{Fe}>5 \%, \mathrm{Ca}<6 \%$, and $\mathrm{P}>1 \%$ for $\mathrm{Mn}-\mathrm{Fe}-\mathrm{P}$ phases, which. In addition to $\mathrm{Ca}$, $\mathrm{Fe}, \mathrm{Mn}$, and $\mathrm{P}$, the contents of $\mathrm{Mg}$ and Si were also determined by the EDX analysis. 
Fluxes of dissolved manganese

Diffusive fluxes of $\mathrm{Mn}_{\text {diss }}$ were calculated from the respective concentration gradients across the SWI according to Fick's first law of diffusion (following the formulas presented by Lewandowski et al. 2002):

$J_{\mathrm{Mn}}=\frac{\varphi}{\theta^{2}} \times D_{\mathrm{Mn}} \times \frac{\Delta C_{\mathrm{Mn}}}{\Delta z}$

with $\mathrm{J}$ is the diffusion rate of $\mathrm{Mn}\left(\mathrm{g} \mathrm{m}^{-2} \mathrm{day}^{-1}\right), \varphi$ is the porosity $\left(\mathrm{m}^{3}\right.$ porewater $/ \mathrm{m}^{3}$ wet sediment $), \theta$ is the tortuosity (unitless), $\mathrm{D}_{\mathrm{Mn}}$ is the molar diffusion coefficient of $\mathrm{Mn}$ in the sediment $\left(6.88 \times 10^{-6} \mathrm{~cm}^{2}\right.$ $\mathrm{s}^{-1}$; Li and Gregory 1974), $\Delta \mathrm{C} / \Delta \mathrm{z}$ is the concentration gradient at the SWI $\left(\mathrm{g} \mathrm{m}^{-4}\right)$. Porosity was calculated as:

$\phi=\frac{\frac{w}{\rho_{\text {water }}}}{\frac{w}{\rho_{\text {water }}}+\frac{1-w}{\rho_{\text {sediment }}}}$

where $w$ is the water content (wt $\% / 100), \rho_{\text {water }}$ density of water at $4{ }^{\circ} \mathrm{C}$. The density of sediment $\left(\rho_{\text {sediment }}\right)$, was calculated as:

$\rho_{\text {sediment }}=\frac{1}{\frac{L O I}{\rho_{\text {org }}}+\frac{1-L O I}{\rho_{\min }}}$,

where LOI is the loss on ignition (wt $\% / 100), \rho_{\text {org }}$ density of organic matter $\left(1.4 \mathrm{~g} \mathrm{~cm}^{-3}\right)$ and $\rho_{\text {min }}$ density mineral matter $\left(2.65 \mathrm{~g} \mathrm{~cm}^{-3}\right)$. Tortuosity was calculated following the formula by Boudreau (1996):

$\theta=\sqrt{1-\ln \phi^{2}}$

To calculate the diffusion coefficient at $4{ }^{\circ} \mathrm{C}$, the following formula as presented by Lewandowski et al. (2002) was used:

$D_{\mathrm{Mn}}=D_{\mathrm{Mn}, 25^{\circ} \mathrm{C}} \times \frac{\mu_{25^{\circ} \mathrm{C}} \times \mathrm{T}}{\mu_{T} \times 298.15 \mathrm{~K}}$,

where $\mu$ is the dynamic viscosity of water at $25{ }^{\circ} \mathrm{C}$ $\left(0.890 \mathrm{~g} \mathrm{~m}^{-1} \mathrm{~s}^{-1}\right)$ and $\mathrm{T}$ is the temperature at the SWI considered as $4{ }^{\circ} \mathrm{C}$. The diffusion coefficient of $\mathrm{D}_{\mathrm{Mn}}$ at $4{ }^{\circ} \mathrm{C}$ was calculated as $3.12 \times 10^{-5} \mathrm{~m}^{2}$ day $^{-1}$. Porosity and tortuosity were determined using the $69.5 \mathrm{~m}$ and $56 \mathrm{~m}$ depth sediment cores for the porewater fluxes at $69.5 \mathrm{~m}$ and $58 \mathrm{~m}$, respectively. The hypolimnetic Mn accumulation was calculated based on the $\mathrm{Mn}_{\text {diss }}$ concentration in different water layers multiplied by the volume of the respective depth interval.

\section{Results}

Sediment investigations

\section{Sediment properties and varve formation}

The upper $<5 \mathrm{~cm}$ of the three deepest cores (between 69.5 and $65 \mathrm{~m}$ ) contained macroscopical varves, represented by variations of $\mathrm{Si}, \mathrm{Ca}$ and $\mathrm{Mn}$ (Fig. 2). In the sediment core obtained at $69.5 \mathrm{~m}$ in August 2017, eight varves were counted within the uppermost $4 \mathrm{~cm}$, so the beginning of continuous varve formation coincidences with the major acceleration of eutrophication in 2010. By comparing the profiles of $\mathrm{Ca}, \mathrm{Mn}$ and $\mathrm{Fe}$ of a core that was sampled at the same site in 2010 (Kleeberg 2014), we can infer that the newly deposited layers amount to $4-5 \mathrm{~cm}$. In contrast, varves were disturbed or absent at the shallower sites. From $12 \mathrm{~cm}$ upwards in the $69.5 \mathrm{~m}$ core, the $\mathrm{Al}$ and TOC contents decreased from 2 to $0.15 \mathrm{wt} \%$ and from 25 to $10 \mathrm{wt} \%$, respectively (Fig. 3). A distinct increase in TIC was observed with a peak of $4.5 \mathrm{wt} \%$ at $9 \mathrm{~cm}$ and $6 \mathrm{wt} \%$ in the upper part of the varved sections. The $\mathrm{Ca}$ content increased almost parallel to TIC and reached a maximum of $16 \mathrm{wt} \%$ at approximately $9 \mathrm{~cm}$. The top part of all of the cores along the transect contained a dark grey, Ca-rich section above $15 \mathrm{~cm}$ depth (Figs. 2 and 4).

\section{Manganese and calcium in sediment cores along a water depth transect}

A distinct surface Mn enrichment was only present in deepest cores below $56 \mathrm{~m}$, and the thickness of the $\mathrm{Mn}$-rich layer increased from $3 \mathrm{~cm}$ in the $56 \mathrm{~m}$ core to $8 \mathrm{~cm}$ in the $69.5 \mathrm{~m}$ core (Fig. 4; see Mn vs. Ti in Figs. S3 and S4 in supplementary material). Furthermore, the Mn content at the SWI increased towards the deepest point, reaching $18 \mathrm{wt} \%$ in $1 \mathrm{~cm}$ intervals (Fig. 3) and up to approximately $45 \mathrm{wt} \%$ in single laminations in the uppermost parts of the cores (Fig. 4). In the $0-5 \mathrm{~cm}$ interval of the core from $38 \mathrm{~m}$ water depth, the ICP-OES derived Mn content was $0.04-0.06 \mathrm{wt} \%$ (see supplementary dataset). In 

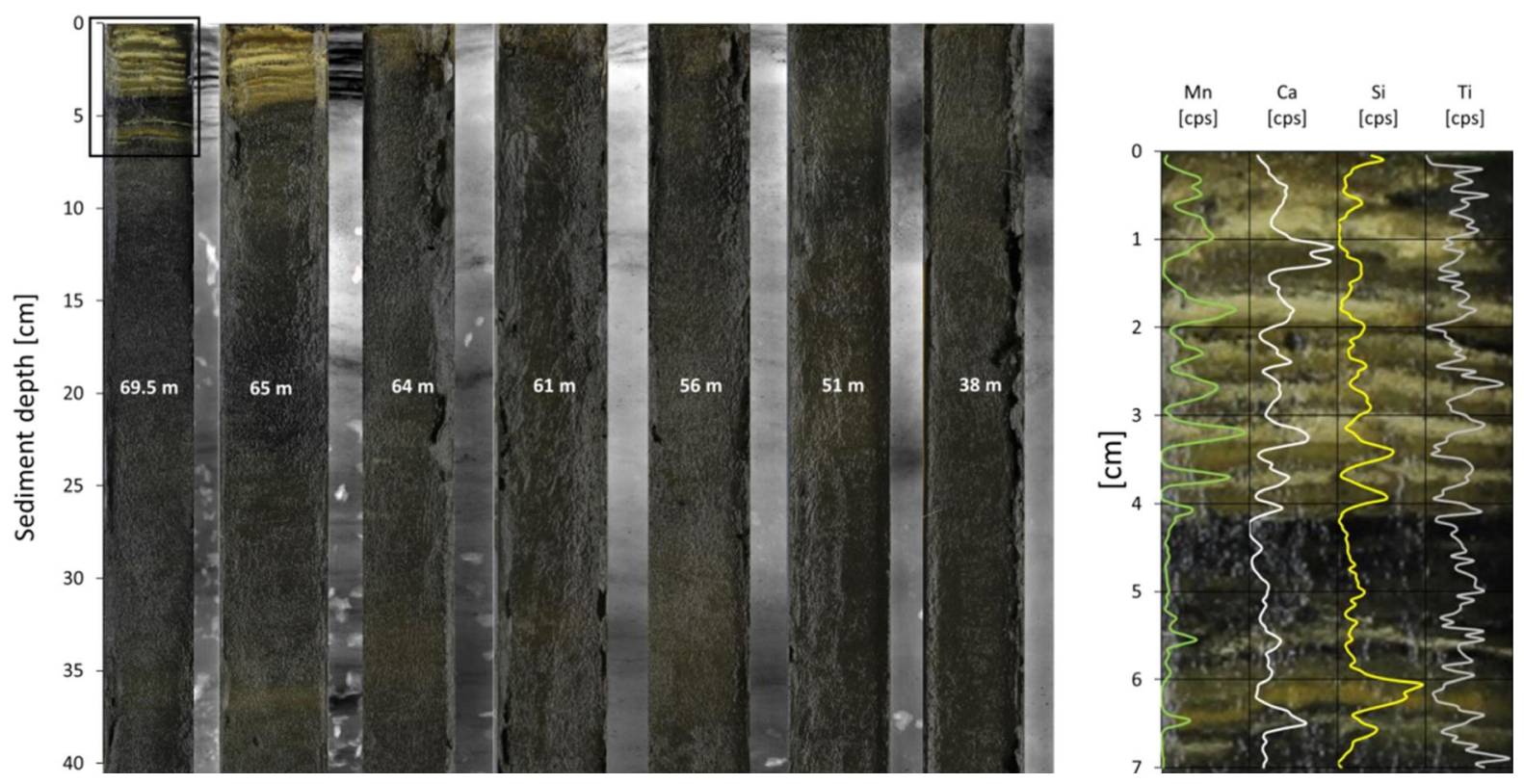

Fig. 2 Left: Photo scans and X-ray pictures (grey scaled) of Lake Stechlin sediment cores sorted from the deepest to the shallowest from left to right. Right: The varved interval of core

contrast to other cores, additional three Mn-rich layers (Figs. 3 and 4) were present in the deepest core $(69.5 \mathrm{~m})$, at sediment depths of $38 \mathrm{~cm}, 31 \mathrm{~cm}$, and $25 \mathrm{~cm}$, and less distinct in the second-deepest core $(65 \mathrm{~m})$. The Mn content in these layers was distinctly lower (max. $6.0 \mathrm{wt} \%$ ) than the Mn enrichment at the core top. The lowermost Mn-rich layer was located in an Al-rich layer, accompanied by increased TIC and Ca contents (Fig. 3). The Mn-rich layers in the middle of the core (at $31 \mathrm{~cm}$ and $25 \mathrm{~cm}$ ) were also accompanied by a weakly increased TIC content, but not by
$69.5 \mathrm{~m}$ scanned by XRF for manganese (Mn), calcium (Ca), silicon $(\mathrm{Si})$, and titanium $(\mathrm{Ti})$ in relative units

increased $\mathrm{Ca}$ or $\mathrm{Al}$ contents. Whilst the $\mathrm{Fe}$ content decreased towards the sediment surface from 7 to 0.7 $\mathrm{wt} \%$, the $\mathrm{Mn} / \mathrm{Fe}$ ratio increased in the Mn-rich upper portions (Fig. 3). The total Mn accumulation in the Mn-rich layer $(0-8 \mathrm{~cm})$ of the $69.5 \mathrm{~m}$ core (sampled on 24 August 2017) was $940 \mathrm{~g} \mathrm{~m}^{-2}$. In comparison, the Mn-rich layer at the top of a core sampled at the same site on 30 October 2010 (Kleeberg 2014) was 4-cm thick and had a $\mathrm{Mn}$ content equivalent to approximately $3 \mathrm{wt} \%$. The calculated Mn accumulation based on this core was $125 \mathrm{~g} \mathrm{~m}^{-2}$, and the
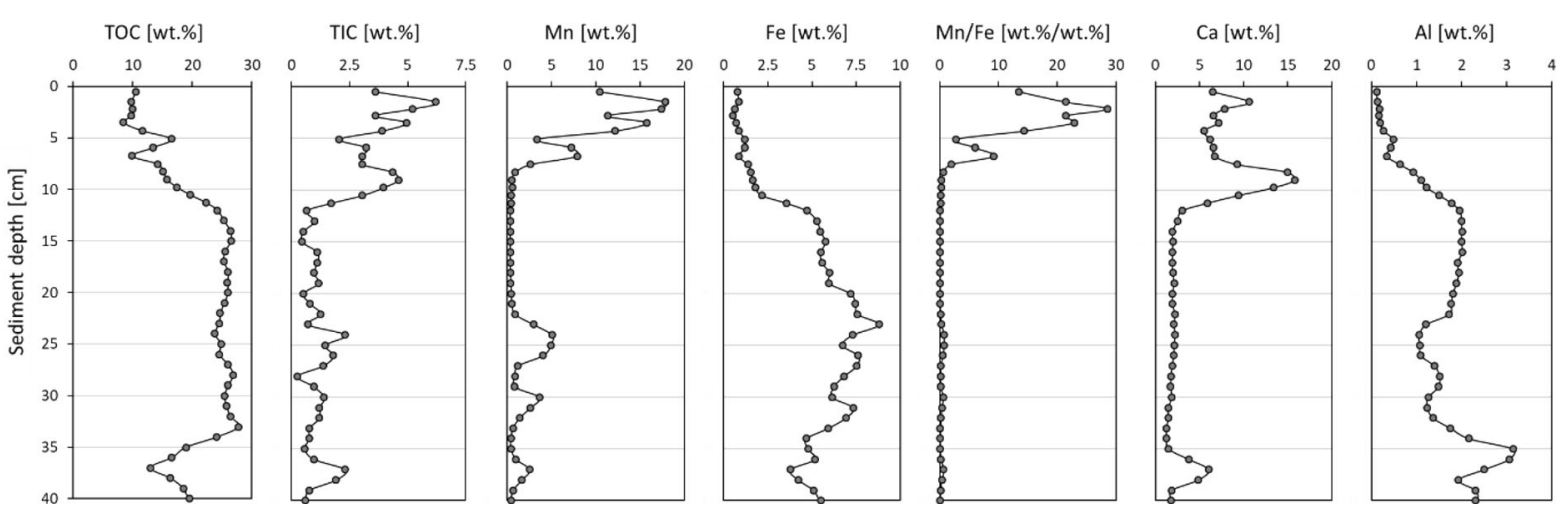

Fig. 3 Vertical distribution of the contents of total organic (TOC), total inorganic carbon (TIC), manganese (Mn), iron (Fe), manganese to iron ratio $(\mathrm{Mn} / \mathrm{Fe})$, calcium $(\mathrm{Ca})$, and aluminium (Al) in Lake Stechlin sediments at the deepest site (core $69.5 \mathrm{~m}$ ) 


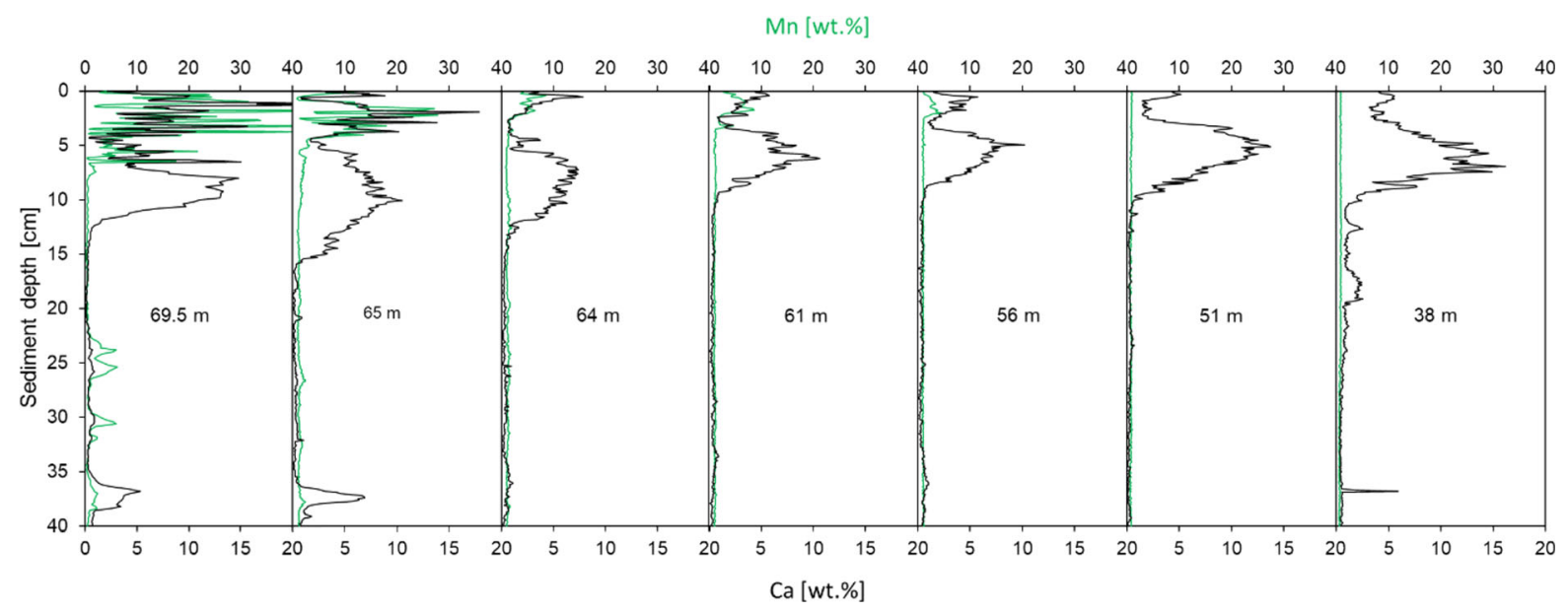

Fig. 4 Contents of manganese (Mn) and calcium $(\mathrm{Ca})$ in the depth-transect of sediment cores in Lake Stechlin (positions see Fig. 1). The contents were calculated by calibration of the relative XRF values with the absolute contents determined by ICP-OES

difference between 2017 and 2010 was $815 \mathrm{~g} \mathrm{~m}^{-2}$, giving a mean accumulation rate of $116 \mathrm{~g} \mathrm{~m}^{-2}$ year $^{-1}$.

Dissolved manganese in the water column

Concentrations of $\mathrm{Mn}_{\text {diss }}$ in the water column showed a clear dependence on the seasonal patterns of stratification and $\mathrm{O}_{2}$ concentrations (Fig. 5). During the summer stratification period on 8 August 2017, $\mathrm{Mn}_{\text {diss }}$ concentrations increased towards the $\mathrm{O}_{2}$-poor bottom waters to a maximum of $0.3 \mathrm{mg} \mathrm{L}^{-1}$ at still oxic conditions of $>5 \mathrm{mg} \mathrm{L}^{-1}$. Manganese concentrations increased up to $0.6 \mathrm{mg} \mathrm{L}^{-1}$ in the bottom waters in September 2017, but unexpectedly decreased to $\sim 0.005 \mathrm{mg} \mathrm{L}^{-1}$ during most $\mathrm{O}_{2^{-}}$ depleted bottom waters at the end of the summer stratification period $\left(<2 \mathrm{mg} \mathrm{L}^{-1}\right.$ in the bottom water column on 12 December 2017; Fig. 5). The $\mathrm{Mn}_{\text {diss }}$ concentration remained low $\left(<0.005 \mathrm{mg} \mathrm{L}^{-1}\right)$ during the following winter mixing period ( 9 January 2018), until the beginning of the next stratification period in spring 2018 when bottom water $\mathrm{Mn}_{\text {diss }}$ rose again to $\sim 0.2 \mathrm{mg} \mathrm{L}^{-1}$ (26 April 2018). During the stratification period in $2018, \mathrm{Mn}_{\text {diss }}$ concentrations increased up to $5 \mathrm{mg} \mathrm{L}^{-1}$ in the few lowermost metres, while the bottom water became oxygen-free.

Porewater concentrations and diffusive fluxes

The $\mathrm{Mn}_{\text {diss }}$ concentrations in the sediment porewaters were up to several times higher than in the water column (Fig. 6). In the core obtained at $58 \mathrm{~m}$ water depth in June, the $\mathrm{Mn}_{\text {diss }}$ profile was almost constant, at approximately $6 \mathrm{mg} \mathrm{L}^{-1}$, with only a slight decrease to $5 \mathrm{mg} \mathrm{L}^{-1}$ at $3 \mathrm{~cm}$ depth and a peak at the SWI that reached $7.6 \mathrm{mg} \mathrm{L}^{-1}$ in June and $11 \mathrm{mg}$ $\mathrm{L}^{-1}$ in November. At $69.5 \mathrm{~m}, \mathrm{Mn}_{\text {diss }}$ concentrations were very similar during November 2017 and June 2018, and were higher than at $58 \mathrm{~m}$; $\mathrm{Mn}_{\mathrm{diss}}$ concentrations peaked with $25 \mathrm{mg} \mathrm{L}^{-1}$ just below the SWI. Notable $\mathrm{Mn}_{\text {diss }}$ concentrations at $69.5 \mathrm{~m}$ were observed in the overlying water column, reaching more than $1.8 \mathrm{mg} \mathrm{L}^{-1}$ in June and $0.2 \mathrm{mg} \mathrm{L}^{-1}$ in November.

At $69.5 \mathrm{~m}$, the diffusive flux of $\mathrm{Mn}$ out of the sediment to the water column was $16.8 \mathrm{~g} \mathrm{~m}^{-2}$ year $^{-1}$ in November and $7.5 \mathrm{~g} \mathrm{~m}^{-2}$ year $^{-1}$ in June. At $58 \mathrm{~m}$, the diffusive flux was $3.2 \mathrm{~g} \mathrm{~m}^{-2}$ year $^{-1}$ in November 2017 and $8.2 \mathrm{~g} \mathrm{~m}^{-2}$ year $^{-1}$ in June 2018. Mean annual fluxes were calculated as the average of the June and November values, i.e. $12.1 \mathrm{~g} \mathrm{~m}^{-2}$ year $^{-1}$ at $69.5 \mathrm{~m}$ and $5.7 \mathrm{~g} \mathrm{~m}^{-2}$ year $^{-1}$ at $58 \mathrm{~m}$.

The dissolved $\mathrm{Ca}$ concentrations $\left(\mathrm{Ca}_{\text {diss }}\right)$ in the porewater and bottom water column in November and June amounted to approximately $40-50 \mathrm{mg} \mathrm{L}^{-1}$ at $58 \mathrm{~m}$ and $69.5 \mathrm{~m}$, with the highest concentrations occurring in June (Fig. 6). In the top $10 \mathrm{~cm}, \mathrm{Ca}_{\text {diss }}$ concentrations dropped by approximately $5 \mathrm{mg} \mathrm{L}^{-1}$ relative to the deeper layers and in the overlying water both in June and November at $69.5 \mathrm{~m}$ and in June at $58 \mathrm{~m}$. Sulphate concentrations decreased abruptly from $26 \mathrm{mg} \mathrm{L}^{-1}$ in the water column to approximately 

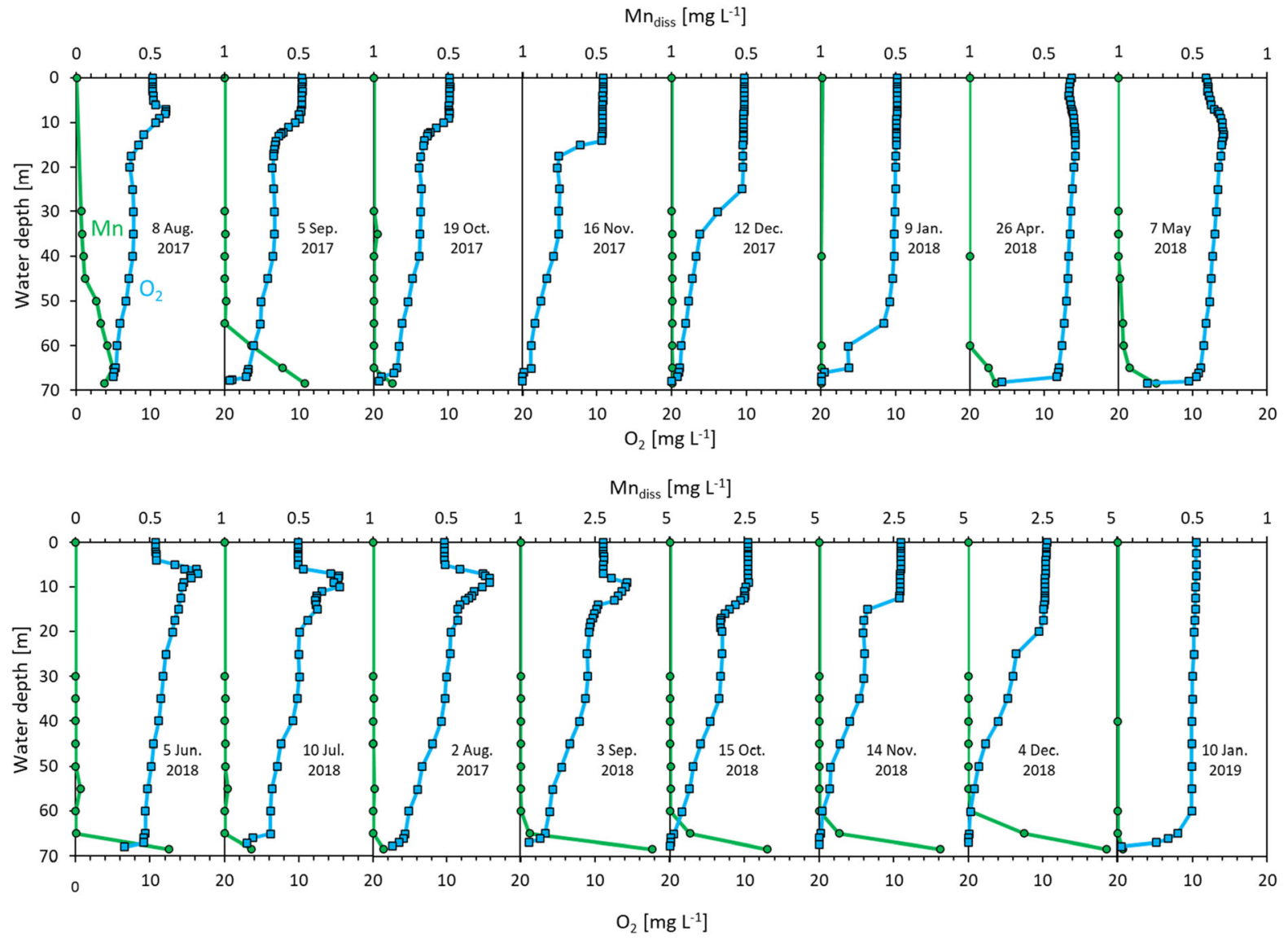

Fig. 5 Dissolved Mn (green; circles) and oxygen (blue; squares) concentrations in the water column of Lake Stechlin at the deepest site $(69.5 \mathrm{~m})$. Note different scale for $\mathrm{Mn}$ concentrations. The mixing period can be recognised by the

$3 \mathrm{mg} \mathrm{L}^{-1}$ in the porewater at both depths in June and November (Fig. 6). The $\mathrm{pH}$ was very similar at both depths and was almost constant in June at approximately 7.6 in the water column and 7.4 in the sediment. In November, $\mathrm{pH}$ increased to 7.8 , reaching a peak just below the SWI relative to the background level in the sediment (7.4) and the water column (7.2). Total dissolved sulphide was absent below $25 \mathrm{~cm}$, increased towards the SWI to $4.4 \mathrm{mg} \mathrm{L}^{-1}$, and dropped to below $0.1 \mathrm{mg} \mathrm{L}^{-1} 10 \mathrm{~cm}$ above the SWI (Fig. 7).

\section{Manganese in sediment traps}

Manganese sedimentation rates showed seasonal variations and were much higher at $60 \mathrm{~m}$ in the water column than at $20 \mathrm{~m}$ (Fig. 8). At the $20 \mathrm{~m}$ water depth, almost constant $\mathrm{O}_{2}$-values during the winter, whereas the stagnation period is characterised by decreased $\mathrm{O}_{2}$-concentrations in bottom waters. Manganese concentrations for the 16 November 2017 are not available. (Color figure online)

the $\mathrm{Mn}$ content in the trap material varied between $<0.1$ and 1.7 wt\% (Fig. 9) with an average of 0.3 wt $\%$ between 2010 and 2018. The Mn sedimentation rate at $20 \mathrm{~m}$ varied between $<0.1$ and $4.8 \mathrm{mg} \mathrm{m}^{-2}$ day $^{-1}$ but did not show any discernible seasonal pattern (Fig. 8). In the trap at $60 \mathrm{~m}$ water depth, the Mn content varied between 0.2 and $26 \mathrm{wt} \%$, with an average of $8.7 \mathrm{wt} \%$ (Fig. 9). The Mn sedimentation rates at $60 \mathrm{~m}$ varied between $3 \mathrm{mg} \mathrm{m}^{-2}$ day $^{-1}$ and $404 \mathrm{mg} \mathrm{m}^{-2}$ day $^{-1}$ with the minima occurring during the mixing period in winter and the maxima occurring during the late stagnation period. Between 2010 and 2017, the total Mn sedimentation recorded by the traps was $4.3 \mathrm{~g} \mathrm{~m}^{-2}$ at $20 \mathrm{~m}$ and $297 \mathrm{~g} \mathrm{~m}^{-2}$ at $60 \mathrm{~m}$ (supplementary dataset). In 2017, the Mn sedimentation rate was $0.7 \mathrm{~g} \mathrm{~m}^{-2}$ year $^{-1}$ at $20 \mathrm{~m}$ and $50.9 \mathrm{~g} \mathrm{~m}^{-2}$ year $^{-1}$ at $60 \mathrm{~m}$. The annual maximum $\mathrm{Mn}$ 

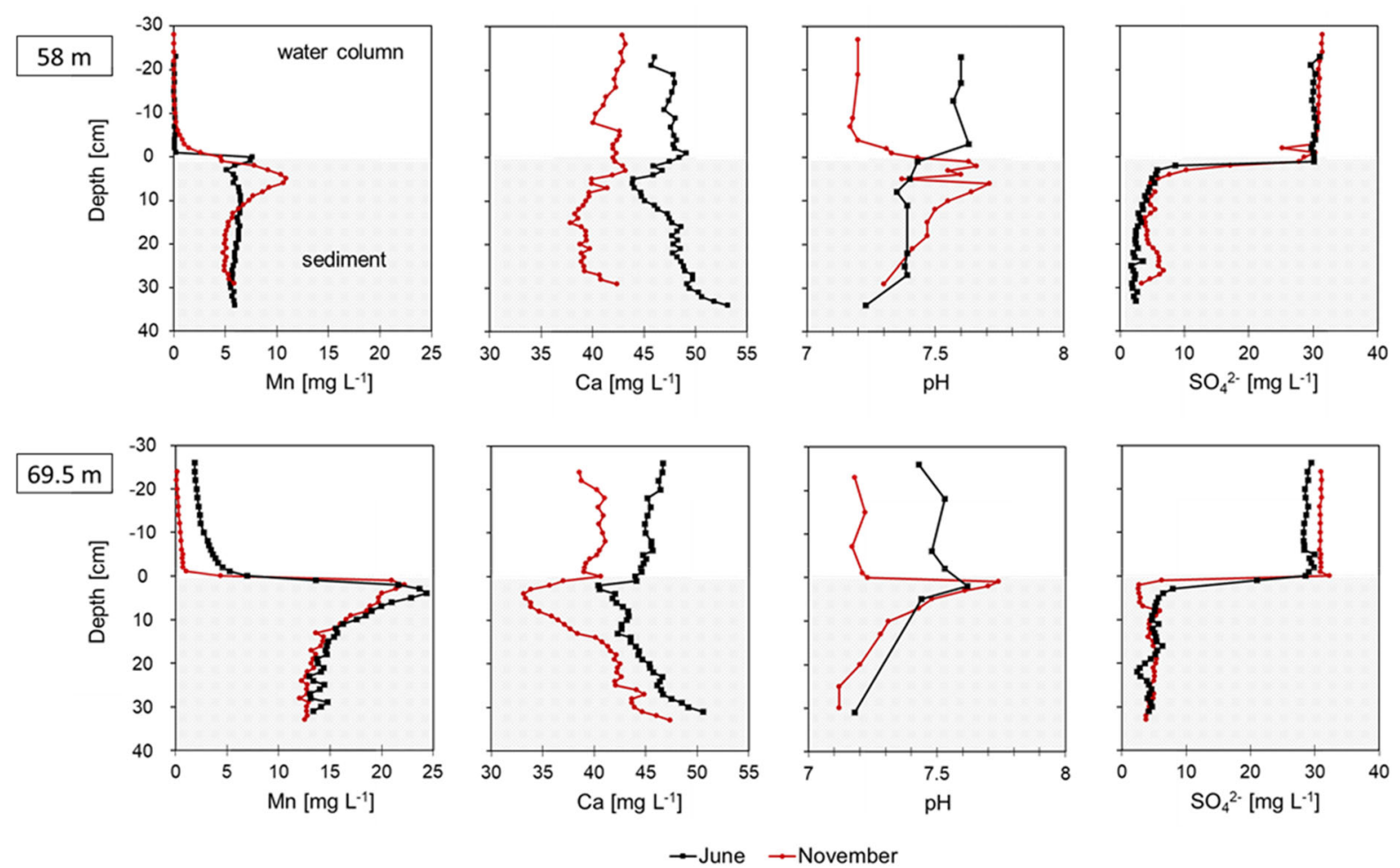

$\rightarrow$ June $\rightarrow$ November

Fig. 6 Porewater (grey area) and water column concentrations of $\mathrm{Mn}_{\text {diss }}, \mathrm{Ca}_{\text {diss }}$, and sulphate as well as $\mathrm{pH}$ values in $58 \mathrm{~m}$ and $69.5 \mathrm{~m}$ water depth (positions see Fig. 1) in Lake Stechlin,

sedimentation rate at $60 \mathrm{~m}$ gradually increased between 2010 and 2012 and has remained constant until at least 2016 (Fig. 8). Minimum $\mathrm{O}_{2}$ concentrations decreased every year, reaching approximately $0.3 \mathrm{mg} \mathrm{L}^{-1}$ by the end of the stagnation period. The

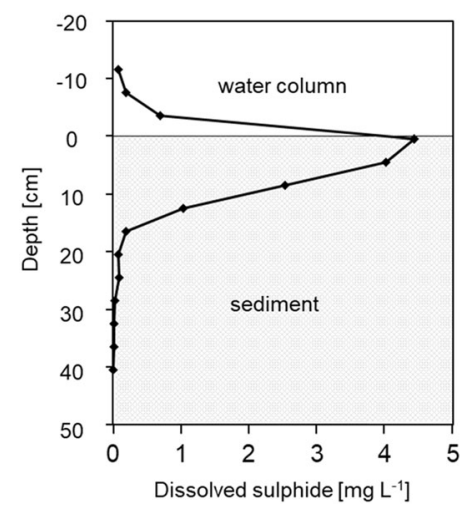

Fig. 7 Dissolved sulphide concentrations in the porewater and water column at the deepest site $(69.5 \mathrm{~m})$ of Lake Stechlin on 19 November 2018 sampled in the early summer during a stratification period (26 June 2018) and before the end of the stratification period in late autumn (29 November 2017)

dry mass sedimentation rate ranged between 0.05 and $1.3 \mathrm{~g} \mathrm{~m}^{-2}$ day $^{-1}$ (average $0.49 \mathrm{~g} \mathrm{~m}^{-2}$ day $^{-1}$ ) in the $20 \mathrm{~m}$ trap and between 0.07 and $8.1 \mathrm{~g} \mathrm{~m}^{-2}$ day $^{-1}$ (average $1.1 \mathrm{~g} \mathrm{~m}^{-2} \mathrm{day}^{-1}$ ) in the $60 \mathrm{~m}$ trap (see Fig. S1 in supplementary material). The highest dry mass sedimentation occurred during the summer period.

The Mn content in the sediment traps deployed during the mixing period at both $20 \mathrm{~m}$ and $60 \mathrm{~m}$ depths in the water column showed a relatively close relation to external sedimentary input represented by Al (Fig. 9). While during the stagnation period, the $\mathrm{Mn}$ vs. Al linear relationship remained fairly unchanged at $20 \mathrm{~m}$, the samples at $60 \mathrm{~m}$ water depth were enriched in $\mathrm{Mn}$ relative to $\mathrm{Al}$ having up to five times higher $\mathrm{Mn}$ contents compared to the trap material obtained during the mixing period.

Manganese fractionation

The Mn fractions differed substantially between the sediment trap material and the surface sediment 


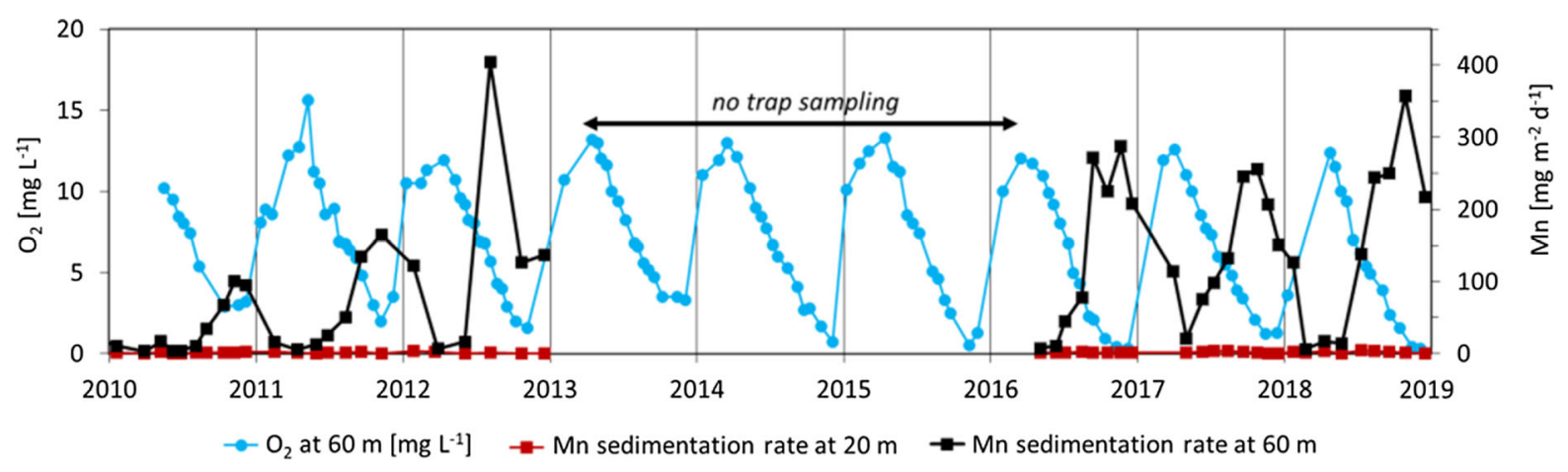

Fig. 8 Time-series of Mn sedimentation rates in $20 \mathrm{~m}$ and $60 \mathrm{~m}$ of the water column and $\mathrm{O}_{2}$ concentration in $60 \mathrm{~m}$ water depth above the deepest site of Lake Stechlin. The Mn sedimentation rates were plotted for the end date of the sediment trap exposure time

(Fig. 10). Sediment trap samples $(60 \mathrm{~m})$ from the end of the stagnation period had an overall high $\mathrm{Mn}$ content of $20 \mathrm{wt} \%$ and $26 \mathrm{wt} \%$ in trap a and $\mathrm{b}$, respectively. The reductive soluble fraction (BD-Mn), representing $\mathrm{MnO}_{\mathrm{x}}$ mineral phases, was most abundant and amounted to ca. $95 \%$ of the total Mn content. The other fractions represented only a minor portion of the total Mn: $<0.1 \%$ was $\mathrm{HCl}-\mathrm{Mn}$, ca. $3 \%$ was $\mathrm{NH}_{4} \mathrm{Cl}-$ $\mathrm{Mn}$, and ca. $2 \%$ was residual Mn. Although dissolution of $\mathrm{MnO}_{\mathrm{x}}$ particles by $\mathrm{HCl}$ is conceivable, the BD-Mn fraction is assumed to have extracted all $\mathrm{MnO}_{\mathrm{x}}$ in the previous extraction step.

While being almost completely absent in the sediment trap material, the $\mathrm{HCl}-\mathrm{Mn}$ fraction, representing Mn carbonates, was most abundant in the surface sediment and amounted to approximately 3.1 $\mathrm{wt} \%$ at $58 \mathrm{~m}$ and $5-7 \mathrm{wt} \%$ at $69.5 \mathrm{~m}$ (equivalent to $54-61 \%$ and $32-52 \%$ of total $\mathrm{Mn}$, respectively). The BD-Mn fraction amounted to $<1 \mathrm{wt} \%$ at $58 \mathrm{~m}$ and $1-3 \mathrm{wt} \%$ at $69.5 \mathrm{~m}$ and, in contrast to the sediment trap material, constituted a minor part of the total $\mathrm{Mn}$ (12-17\% and $10-13 \%$, respectively). It is notable that the $\mathrm{NH}_{4} \mathrm{Cl}-\mathrm{Mn}$ fraction yielded higher values at $69.5 \mathrm{~m}(2.7-8 \mathrm{wt} \%)$ than in $58 \mathrm{~m}$ (approximately 1 $\mathrm{wt} \%$ ), and that the content of the BD-Mn fraction decreased slightly while the $\mathrm{HCl}-\mathrm{Mn}$ fraction increased from 0 to $1 \mathrm{~cm}$ towards $1-2 \mathrm{~cm}$ depths (Fig. 10).

\section{SEM-EDX analysis}

Of the sediment trap particles, $67 \%$ were identified as Mn oxides and $2.7 \%$ as Mn carbonates (supplementary dataset). Further $8.2 \%$ of the particles were referred to as Mn-Fe-P-rich particles, as described in more detail by Dellwig et al. (2010). The Mn oxides from the trap material had variable sizes ranging from a few to hundreds of micrometres (Fig. 11), were poorly crystalline and branching vermicular in shape, resembling Mn oxides described in previous studies (Dellwig et al. 2012, 2018; Schnetger and Dellwig 2012). The Mn oxides from the $60 \mathrm{~m}$ trap typically contained only a small amount of $\mathrm{Ca}(2.4 \mathrm{wt} \%)$, resulting in a high molar $\mathrm{Mn} / \mathrm{Ca}$ ratio of approximately 14 . As further accessory elements $\mathrm{Fe}(3.1 \mathrm{wt} \%), \mathrm{P}(1.2 \mathrm{wt} \%)$, $\mathrm{Si}(2.8 \mathrm{wt} \%)$ as well as trace amounts of S $(0.4 \mathrm{wt} \%)$ and $\mathrm{Mg}(0.1 \mathrm{wt} \%)$ were determined, with the last two element contents within the range of the EDX detection limit.

In the $0-1 \mathrm{~cm}$ sediment horizon at a depth of $69.5 \mathrm{~m}, 8 \%$ of the particles were identified as $\mathrm{Mn}$ oxides, $67 \%$ as Mn carbonates, and $1 \%$ as Mn-Fe-Prich particles. In the 1-2 cm horizon of the same core, the proportion of Mn oxides dropped to $1.3 \%$, whereas $42 \%$ were $\mathrm{Mn}$ carbonates and $1.2 \%$ were classified as $\mathrm{Mn}$-Fe-P-rich particles. The Mn carbonate particles had a size of approximately $2 \mu \mathrm{m}$, were spherical smooth-edge rhombohedral or "almond-like" in shape, had an average stoichiometry of $\left(\mathrm{Mn}_{0.79}\right.$ $\left.\mathrm{Ca}_{0.21}\right) \mathrm{CO}_{3}$, and are grouped into larger aggregates (Fig. 11; supplementary dataset). Unlike in Mn carbonates from the Big Watab Lake in the USA (Stevens et al. 2000) or in the Landsort Deep (Häusler et al. 2018), the deepest basin in the Baltic Proper, no $\mathrm{Mg}$ could be determined in the Mn carbonate phase, but significant amounts of Si (2.9 wt \%), Fe (0.5 wt \%), P $(1.2 \mathrm{wt} \%)$, and $\mathrm{S}(1 \mathrm{wt} \%)$ were present. 

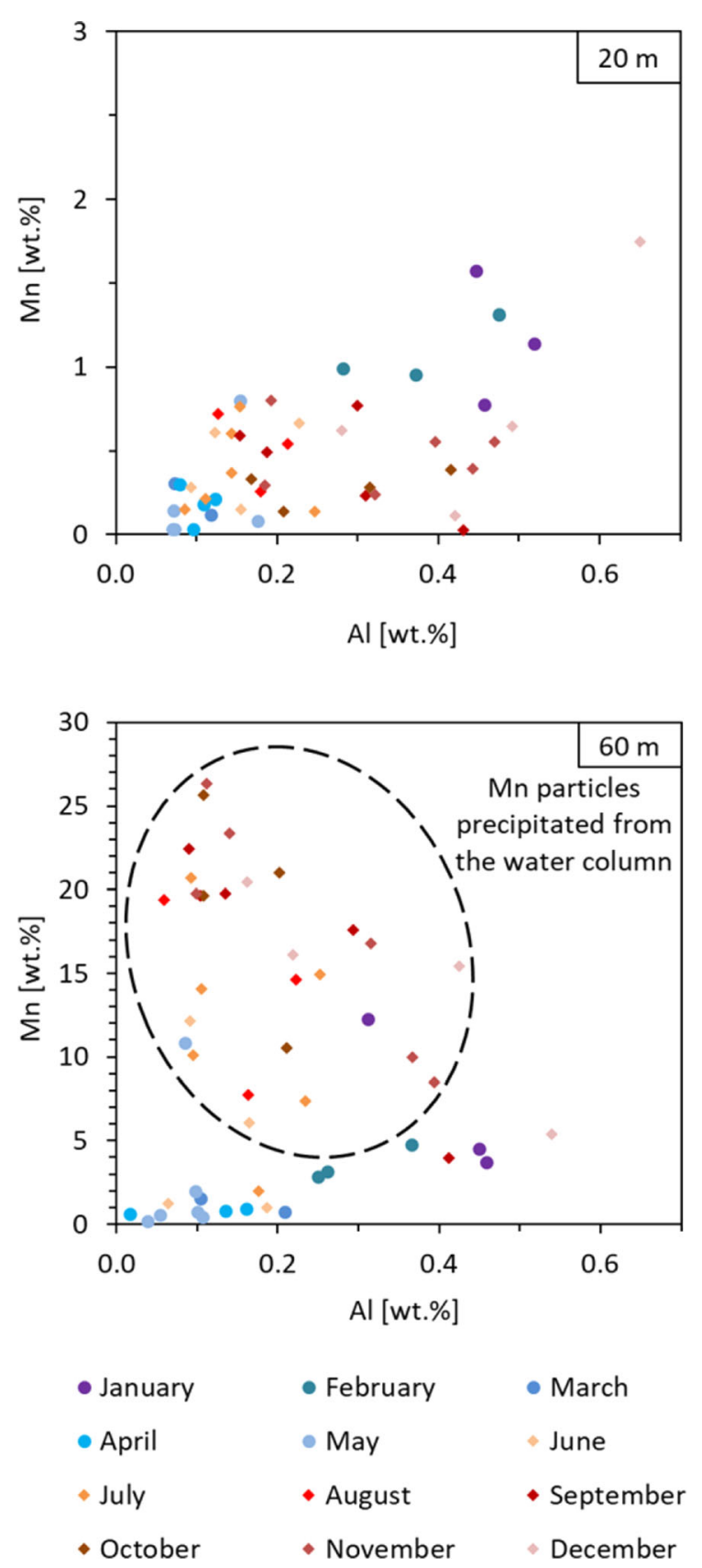

Fig. 9 Cross-plots of $\mathrm{Mn}$ vs. Al contents of the sediment trap material from $20 \mathrm{~m}$ and $60 \mathrm{~m}$ water depth at the deepest site of Lake Stechlin. The months were assigned to sampled middle day of exposure of the traps. The values in the circle represent samples that contain $\mathrm{Mn}$ precipitated during sedimentation between 20 and $60 \mathrm{~m}$. (Color figure online)

\section{Discussion}

Manganese enrichment in sediments of Lake Stechlin

Sediments of Lake Stechlin in this study were found to be enriched in $\mathrm{Mn}$ only below $56 \mathrm{~m}$ water depth (Fig. 4), accounting for a relatively small area of approximately $3.9 \%$ of the total lake. During a field campaign in 1991, Mn content was determined in 51 surface sediments from various depths between $>1$ and $69.5 \mathrm{~m}$ in the Lake Stechlin (Casper et al. 1995). It was observed that the deepest site contained the most $\mathrm{Mn}$, although the contents of Mn found in the surface sediments were much lower (a maximum of $1.3 \mathrm{wt} \%$ ) than determined in this study.

This Mn-rich upper layer postdates the onset of calcite $\left(\mathrm{CaCO}_{3}\right)$ precipitation (Figs. 3 and 4$)$ that was dated to approximately 1900-1930 (Casper 1994; Gonsiorczyk et al. 1995). The calcite precipitation in Lake Stechlin was explained by increased $\mathrm{CO}_{2}$ assimilation by primary production and increased water temperature (Koschel et al. 1985). The appearance of the Mn-rich layer slightly pre-dates the appearance of varves, which occurs in the uppermost section of the deepest core and can be counted back from 2017 to 2010 (Fig. 2). As such, the Mn-rich deposits coincide with the major drop in $\mathrm{O}_{2}$ in the hypolimnion in 2010. Such a trend of increasing Mn accumulation alongside decreasing $\mathrm{O}_{2}$ concentrations was also documented in the sediment trap record since 2010 (Fig. 8). Varve formation resulted from the seasonal and sequential enhanced sedimentation of organic matter, calcite, opal, and $\mathrm{MnO}_{\mathrm{x}}$ as a direct or indirect result of increased primary productivity and a lack of bioturbating organisms.

Manganese mineral phases

Manganese minerals in the water column collected by the sediment traps at $60 \mathrm{~m}$ were $\mathrm{MnO}_{\mathrm{x}}$ particles, according to SEM-EDX (Fig. 11). These particles were the dominant phase of the settling seston, as shown by particle counting under the SEM-EDX and a very high (95\%) proportion of (reductive-soluble) BDMn fraction in the total Mn (Fig. 10). The relationship between $\mathrm{Mn}$ and $\mathrm{Al}$ for the particles mostly deposited during the oxygenated mixing phase (Fig. 9) could be considered as a background Mn sedimentation during 
(a) Mn content [wt.\%]

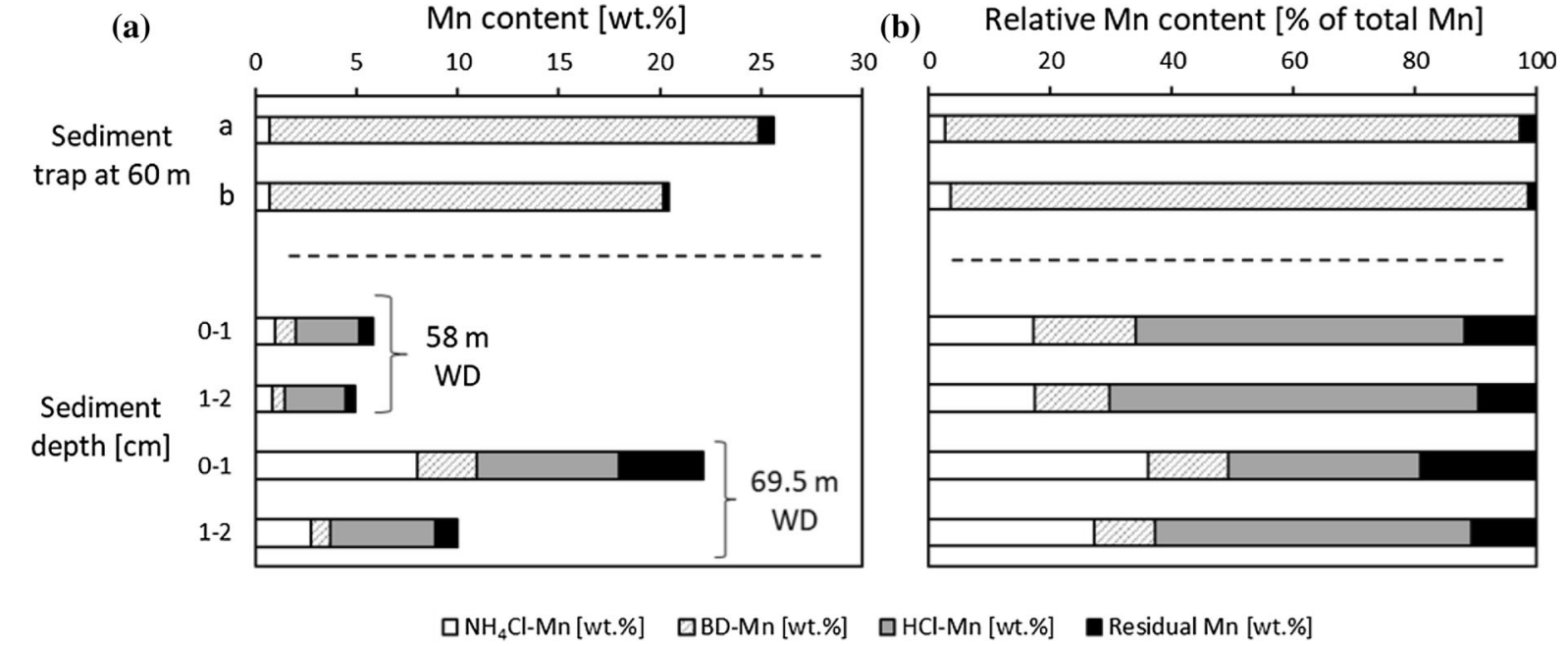

(b) Relative $\mathrm{Mn}$ content [\% of total $\mathrm{Mn}$ ]

Fig. 10 Left: contents of the four $\mathrm{Mn}$ fractions from the sequential extraction in the sediment trap material in $60 \mathrm{~m}$ (above) obtained on a 19 September-29 October 2018 and b 29

Sediment trap, 60 m, 19. Sep. - 29. Oct. 2018

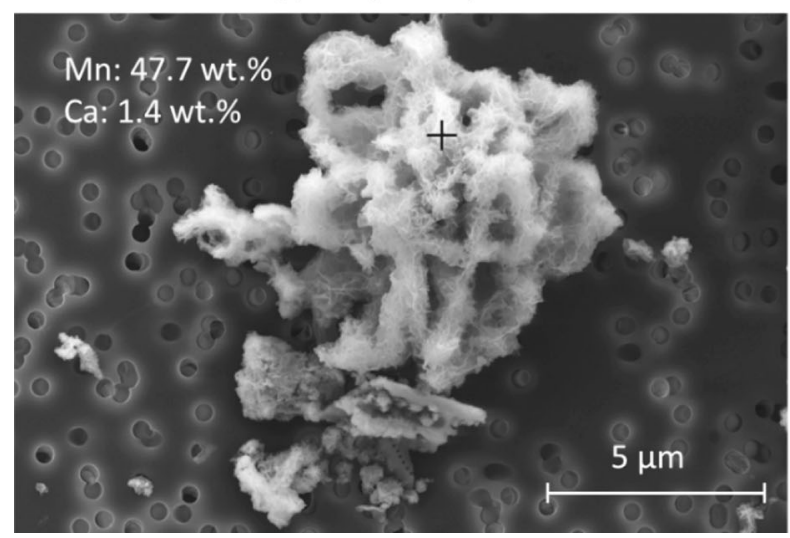

Fig. 11 Exemplary SEM-photograph showing a $\mathrm{MnO}_{\mathrm{x}}$ particle (ID 6997) from the $60 \mathrm{~m}$ sediment trap (left) and $\mathrm{Mn}(\mathrm{Ca}) \mathrm{CO}_{3}$ particles (ID 1466) in the surface sediment (right) at the deepest

periods where the redoxcline is near or within the sediment. High Mn contents and $\mathrm{Mn} / \mathrm{Al}$ ratios in the $60 \mathrm{~m}$ traps (Fig. 9) indicate that $\mathrm{MnO}_{\mathrm{x}}$ particles precipitated from the water column during stratification.

In contrast to the trap material, SEM-EDX indicated that the dominant phase in the sediment was Carich rhodochrosite $\left(\mathrm{Mn}(\mathrm{Ca}) \mathrm{CO}_{3}\right.$; Fig. 11) when compared with studies on the structural and chemical composition of Ca-rich rhodochrosite in the hypoxic/ euxinic basins of the Baltic Sea (Suess 1979; Dellwig et al. 2018; Häusler et al. 2018). The presence of this
October-18 December 2018 and of the sediments at $58 \mathrm{~m}$ and $69.5 \mathrm{~m}$ water depth (below). Right: contents of the Mn fractions normalised to the total Mn content

Sediment, 1-2 cm, 69.5 m, 19 Nov. 2018

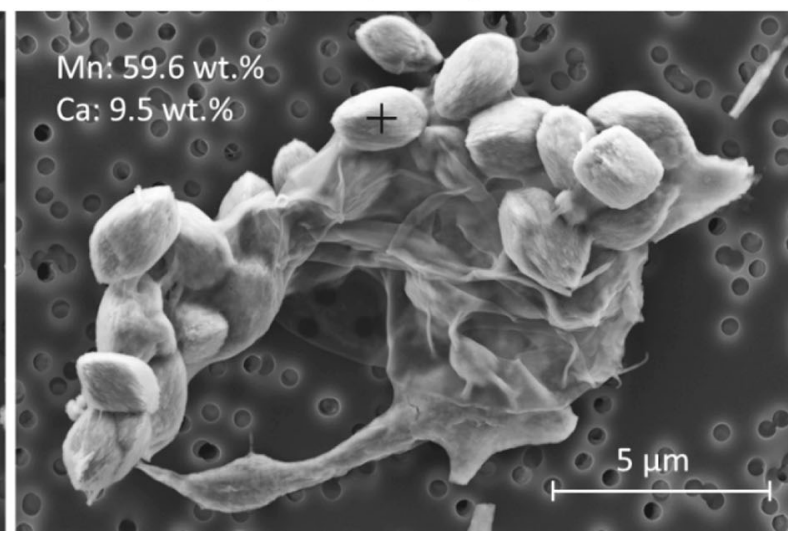

site of Lake Stechlin. Crosses mark the spots of the EDX elemental analyses. Additional SEM-EDX data are provided in the supplementary dataset

mineral phase was also suggested by the high amounts of HCl-soluble Mn (Fig. 10) and TIC (Fig. 3) that indicated an existence of both $\mathrm{Mn}$ and $\mathrm{Ca}$ carbonates. Similar enrichments in $\mathrm{Mn}(\mathrm{Ca}) \mathrm{CO}_{3}$ must have occurred in the past, as evidenced by the Mn layers in lower sections of the deepest core (Figs. 3 and 4). The Ca-rich mixed phases are not expected in the two Mn-rich middle sections $(31 \mathrm{~cm}$ and $25 \mathrm{~cm})$ of the deepest core $(69.5 \mathrm{~m})$ as the $\mathrm{Ca}$ signal remained low in these layers (Fig. 3). The increased $\mathrm{Mn}, \mathrm{Ca}$, and TIC contents within the detritus-rich interval (at $38 \mathrm{~cm}$ depth) suggested the presence of $\mathrm{Mn}(\mathrm{Ca}) \mathrm{CO}_{3}$. 
Previously, Röper and Schwarz (2003) detected Carich rhodochrosite, using XRD, in a core collected from the deepest part of Lake Stechlin in 1993, in a layer below $25 \mathrm{~cm}$, that should correspond with the Mn-rich interval observed in our study at $38 \mathrm{~cm}$ depth.

\section{Formation of $\mathrm{Mn}(\mathrm{Ca}) \mathrm{CO}_{3}$}

The distinct difference between the dominance of $\mathrm{MnO}_{\mathrm{x}}$ in the water column and $\mathrm{Mn}(\mathrm{Ca}) \mathrm{CO}_{3}$ at the sediment surface indicated that $\mathrm{Mn}(\mathrm{Ca}) \mathrm{CO}_{3}$ formation has taken place at the SWI. We suppose that a mineral phase transition from $\mathrm{Mn}$ oxide to $\mathrm{Mn}$ carbonate required reductive dissolution of deposited $\mathrm{MnO}_{\mathrm{x}}$ and re-precipitation as $\mathrm{Mn}(\mathrm{Ca}) \mathrm{CO}_{3}$. An active diagenetic transformation of $\mathrm{MnO}_{\mathrm{x}}$ to $\mathrm{Mn}(\mathrm{Ca}) \mathrm{CO}_{3}$ was confirmed by the downward trend of BD-Mn loss in favour of $\mathrm{Mn}-\mathrm{HCl}$ (Fig. 10). The confined stratigraphic appearance of $\mathrm{Mn}$ peaks (Fig. 2) further points to a quick conversion of $\mathrm{MnO}_{\mathrm{x}}$ into $\mathrm{Mn}(\mathrm{Ca}) \mathrm{CO}_{3}$ and successful burial close to the SWI rather than dispersed post-depositional re-precipitation as also suggested for the Landsort Deep by Häusler et al. (2018). Sedimentation of $\mathrm{MnO}_{\mathrm{x}}$ was not abrupt but continuous and occurred mainly along the stagnation period from about April until December, as evidenced by the sediment traps (Fig. 8). Precipitation of calcite in Lake Stechlin occurs in June-July, and the particulate $\mathrm{Mn}$ nearly co-appears with calcite, as shown by the parallel occurrence of $\mathrm{Ca}$ and $\mathrm{Mn}$ peaks in the varved section (Fig. 2). An abrupt sedimentation or formation of particulate Mn, e.g. due to mixing with oxygenated surface waters, would have rather resulted in single thick Mn-laminations. Several factors may favour the authigenesis of $\mathrm{Mn}(\mathrm{Ca}) \mathrm{CO}_{3}$, as for instance high porewater $\mathrm{Mn}_{\text {diss }}$ concentrations (Fig. 6), which result from the reductive dissolution of abundant $\mathrm{MnO}_{\mathrm{x}}$ at the SWI (Figs. 4 and 10). Formation and burial of $\mathrm{Mn}$ as $\mathrm{Mn}(\mathrm{Ca}) \mathrm{CO}_{3}$ did not occur and apparently was not possible in sediments at shallower water depths. We attribute this to insufficient amounts of reducible $\mathrm{MnO}_{\mathrm{x}}$, a higher water column $\mathrm{O}_{2}$ levels inhibiting $\mathrm{MnO}_{\mathrm{x}}$ reduction, and an insufficient input of reactive organic matter to induce persistently reducing conditions at the SWI.

The first step for $\mathrm{Mn}(\mathrm{Ca}) \mathrm{CO}_{3}$ authigenesis, i.e. the reduction of $\mathrm{MnO}_{\mathrm{x}}$, may be mediated directly by porewater sulphide (e.g. Burdige 1993; Yao and Millero 1993) or microbes (e.g. Aller and Rude
1988; Neumann et al. 2002; Tebo et al. 2004; Lee et al. 2011; Henkel et al. 2019). Active bacterial sulphate reduction and the involvement of sulphide in $\mathrm{MnO}_{\mathrm{x}}$ reduction is supported by the rapid drop in sulphate concentrations and the peak in sulphide concentrations at the SWI (Figs. 6 and 7). In addition, bacterial sulphate reduction may also result in significant alkalinity, thus favouring $\mathrm{Mn}(\mathrm{Ca}) \mathrm{CO}_{3}$ precipitation (Berner et al. 1970; Huckriede and Meischner 1996).

The calcite-rich top portion of the sediment (Fig. 2) suggested that dissolution of calcite at the SWI is a potential source of carbonate ions for the $\mathrm{Mn}(\mathrm{Ca}) \mathrm{CO}_{3}$ authigenesis; however, the $\mathrm{Mn}$ intervals at $31 \mathrm{~cm}$ and $25 \mathrm{~cm}$ within the deepest core contained no Caenrichments, which suggest that the presence of calcite was not obligatory for past $\mathrm{Mn}(\mathrm{Ca}) \mathrm{CO}_{3}$ formation (Fig. 4). The slightly basic $\mathrm{pH}$ of the porewater (Fig. 6) does not support calcite dissolution as a source of $\mathrm{Ca}$ and carbonate ions. More likely, carbonate ions may be the product of oxidised organic matter. Indeed, based on low $\delta^{13} \mathrm{C}$ isotope ratios (Suess 1979; Huckriede and Meischner 1996; Lepland and Stevens 1998; Stevens et al. 2000; Neumann et al. 2002), a significant portion of the carbonate involved in $\mathrm{Mn}(\mathrm{Ca}) \mathrm{CO}_{3}$ formation must come from organic matter degradation. In contrast, Pedersen and Price (1982) reported $\delta^{13} \mathrm{C}$ data that indicated a non-organic source of carbonate in $\mathrm{Mn}(\mathrm{Ca}) \mathrm{CO}_{3}$. Nevertheless, the degradation of organic matter-the sedimentation of which has increased since the onset of eutrophication of Lake Stechlin-likely has provided the carbonate ions for the $\mathrm{Mn}(\mathrm{Ca}) \mathrm{CO}_{3}$ authigenesis. The addition of $\mathrm{Ca}$-ions to the mixed $\mathrm{Mn}-\mathrm{Ca}$ phase does not necessarily require the dissolution of $\mathrm{CaCO}_{3}$ to $\mathrm{Ca}^{2+}$ as the water of Lake Stechlin is already rich in $\mathrm{Ca}^{2+}$ (Fig. 6). The decrease of $\mathrm{Ca}^{2+}$ in the porewater during the summer stagnation period also does not support the scenario of $\mathrm{CaCO}_{3}$ dissolution. Instead, it points to the precipitation of $\mathrm{Ca}^{2+}$ as $\mathrm{Mn}(\mathrm{Ca}) \mathrm{CO}_{3}$. During the oligotrophic period, conditions necessary for $\mathrm{Mn}$ carbonate formation were probably not met, and $\mathrm{Mn}$ was cycling between the water column and the sediment without being buried.

Fluxes and redistribution of manganese

Calculations of internal Mn fluxes were made to explain the source and sedimentation patterns of $\mathrm{Mn}$ 
and were summarised in Fig. 12. The flux of porewater $\mathrm{Mn}_{\text {diss }}$ below $58 \mathrm{~m}$ water depths cannot explain the $\mathrm{Mn}$ accumulation into the $60 \mathrm{~m}$ trap alone; the porewater fluxes measured at $58 \mathrm{~m}$ and $69.5 \mathrm{~m}$ did not exceed $16.8 \mathrm{~g} \mathrm{Mn} \mathrm{m}^{-2}$ year $^{-1}$, so were much lower than the Mn accumulation rate of $50.9 \mathrm{~g} \mathrm{~m}^{-2}$ year $^{-1}$ in the trap at $60 \mathrm{~m}$. Therefore, porewater fluxes from shallower areas must contribute as well. Although distinctly lower compared to the central lake, a Mn flux into the overlying water also occurs in the porewaters of the shallower areas. Thus, Mn release rates vary between 0.3 and $36 \mathrm{mg} \mathrm{Mn} \mathrm{m}^{-2}$ day $^{-1}$ on a transect carried out from 17 to $68 \mathrm{~m}$ water depth in May-July 2017 (Lungfiel 2018; Fig. S2 and Table $\mathrm{S} 1$ in supplementary material). Relating this data to the large source area between 0 and $60 \mathrm{~m}$ water depth $\left(4.15 \mathrm{~km}^{2}\right)$, a total Mn mass of $3078 \mathrm{~kg}_{\text {year }}{ }^{-1}$ $\left(0.74 \mathrm{~g} \mathrm{~m}^{-2}\right.$ year $\left.^{-1}\right)$ could be theoretically released into the water, and $37.2 \mathrm{~g} \mathrm{~m}^{-2}$ year ${ }^{-1}$ could be deposited in the small sink area $\left(0.08 \mathrm{~km}^{2}\right)$ below $60 \mathrm{~m}$ depth. Despite existent inaccuracies, this is in the order of magnitude of the mean additional $\mathrm{Mn}$ accumulation in the sediments $\left(50.9 \mathrm{~g} \mathrm{~m}^{-2}\right.$ year $^{-1}$; Fig. 12). Lake-external $\mathrm{Mn}$ inputs are excluded as significant sources for Mn enrichment in deeper parts because there were no major environmental changes in the watershed area in the last decades that would explain an intensified $\mathrm{Mn}$ input to the lake and its geochemical focussing. Groundwater as the presumed main source of Mn could not have caused such Mn enrichment at the deepest sites directly, as it enters Lake Stechlin at the shoreline (Pöschke et al. 2018).

Manganese enrichment at the sediment surface was present below the $56 \mathrm{~m}$ water depth (Fig. 12), although a certain portion was not permanently fixed as $\mathrm{Mn}(\mathrm{Ca}) \mathrm{CO}_{3}$ but was still present as $\mathrm{MnO}_{\mathrm{x}}$ (Fig. 10) and will be subject to ongoing redistribution. The difference between total $\mathrm{Mn}$ accumulated at the SWI at the deepest site in $2010\left(125 \mathrm{~g} \mathrm{~m}^{-2}\right)$ and 2017 $\left(940 \mathrm{~g} \mathrm{~m}^{-2}\right)$ is $815 \mathrm{~g} \mathrm{~m}^{-2}$. However, the sediment trap at $60 \mathrm{~m}$ in the water column above the deepest site recorded a Mn accumulation of just $297 \mathrm{~g} \mathrm{~m}^{-2}$ during this period. The difference between the amount of $\mathrm{Mn}$ accumulated in the sediment and the sediment trap is explained by the lateral, near-sediment transport of an additional $518 \mathrm{~g} \mathrm{~m}^{-2}$ year $^{-1}$ beneath the sediment trap at $60 \mathrm{~m}$. Furthermore, the highest mass per square meter of $\mathrm{Mn}_{\text {diss }}$ in the water column above the $69.5 \mathrm{~m}$ site was obtained on 8 August 2017, and equalled
$5.5 \mathrm{~g} \mathrm{~m}^{-2}$ (Fig. 12). This amount is approximately 10-times smaller than the accumulation in the trap at $60 \mathrm{~m}\left(50.9 \mathrm{~g} \mathrm{year}^{-1}\right)$ and is much lower than the average known amount of deposited $\mathrm{Mn}$ in the period 2010-2017 (116 g year ${ }^{-1}$ ). Therefore, the Mn measured in the water column cannot explain the overall $\mathrm{Mn}$ accumulation rates, but instead, $\mathrm{MnO}_{\mathrm{x}}$ must be repeatedly dissolved and precipitated.

\section{Geochemical focusing}

Based on the observations and mass balance calculations, a conceptual model of the geochemical focusing and diagenesis of Mn in Lake Stechlin was developed (numbers 1 through 8 in Fig. 13). (1) The intensification of all redox-related processes at the SWI can be attributed to the supply of labile organic matter due to increased primary production during a recent period of eutrophication. (2) In addition, $\mathrm{pH}$ seasonally increases due to $\mathrm{CO}_{2}$ uptake by phototropic organisms leading to calcite precipitation from the epilimnion in summer. (3) The degradation of organic matter (OM) consumes $\mathrm{O}_{2}$ leading to anoxic conditions at the SWI resulting in a reduction of particulate $\mathrm{MnO}_{\mathrm{x}}$ to $\mathrm{Mn}_{\text {diss }}$ in the porewater forming a peak at the SWI (Fig. 6). Because $\mathrm{Mn}_{\text {diss }}$ has already accumulated in the water column during the beginning of the stagnation period (26. April 2018 in Fig. 5), the mobilisation of Mn can be attributed to the reductive dissolution of $\mathrm{MnO}_{\mathrm{x}}$ by organic matter degradation coming from algae blooms in spring, rather than to stagnation duration. A similar increase in $\mathrm{Mn}_{\text {diss }}$ in porewater and in water column during spring/summer has been reported in Lake Mendota (Wisconsin, USA) by Delfino and Lee (1971), Oneida Lake (New York, USA) by Aguilar and Nealson (1998), the seasonally anoxic Lake Rostherne Mere, UK (Davison and Woof 1984), and Esthwaite Water, UK (Hamilton-Taylor et al. 1996). The long water residence time of Lake Stechlin of $>40$ years (Koschel and Adams 2003), resulting from a lack of major watercourses, is probably a major factor enabling Mn cycling and prevents the outflow of $\mathrm{Mn}_{\text {diss. }}$ (4) After the reductive dissolution of $\mathrm{MnO}_{\mathrm{x}}$ and diffusion of $\mathrm{Mn}_{\text {diss }}$ into the water column (Fig. 5), $\mathrm{Mn}_{\text {diss }}$ is oxidised to $\mathrm{MnO}_{\mathrm{x}}$ (Figs. 10 and 11). (5) The transportation and focusing of the particulate $\mathrm{MnO}_{\mathrm{x}}$ towards greater water depths can be explained by diffusion of $\mathrm{Mn}_{\text {diss }}$ within the water column and, as proposed by Schaller and Wehrli (1996), by the 


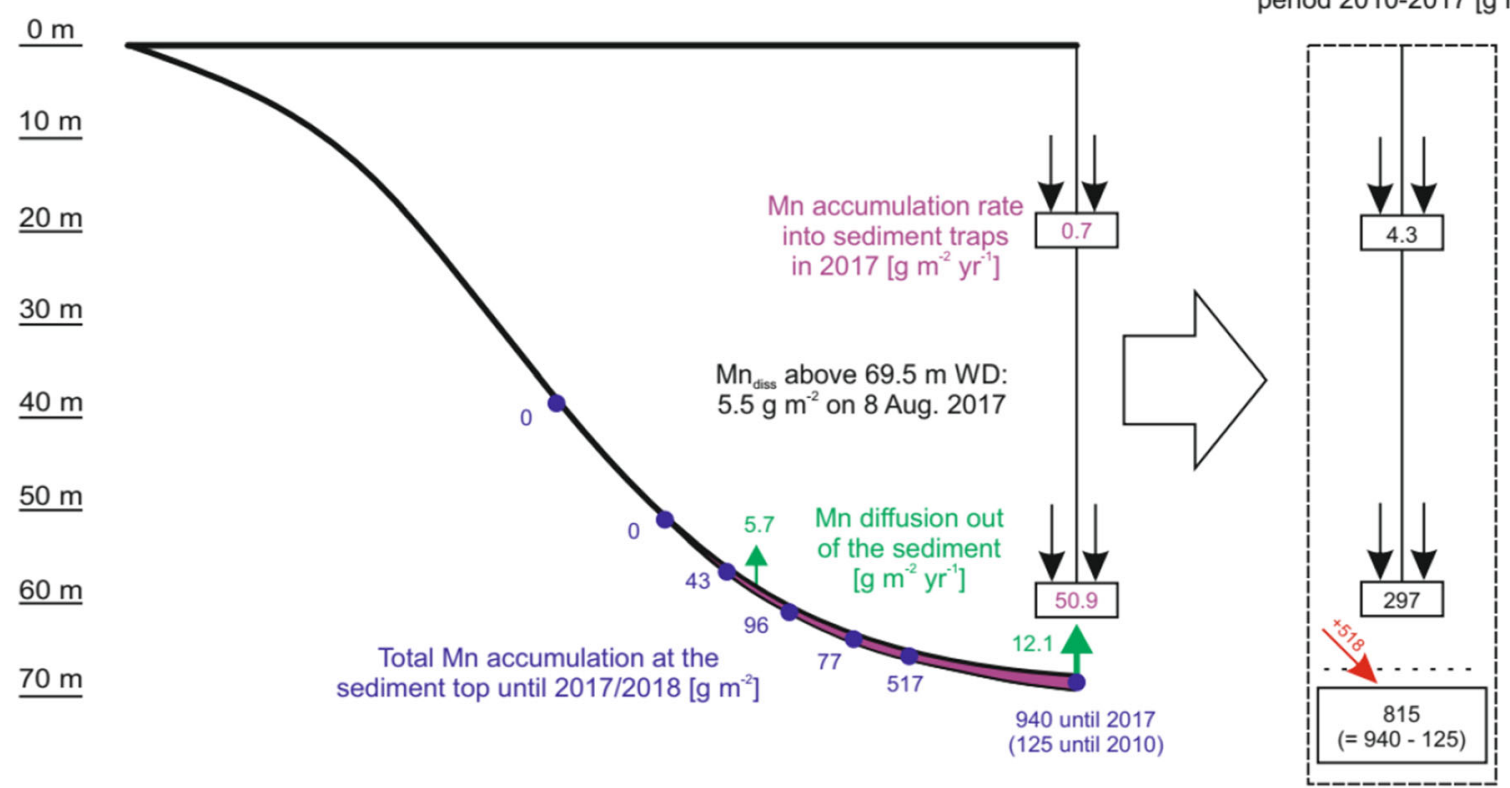

Total $\mathrm{Mn}$ accumulation in the period 2010-2017 [g m $\left.{ }^{-2}\right]$

Fig. 12 Balance of Mn fluxes in Lake Stechlin. The maximum encountered total $\mathrm{Mn}_{\text {diss }}$ mass in the water column was measured on 8 August 2017 (WD: water depth); dark-blue text $=$ total accumulation of $\mathrm{Mn}$ at the sediment surface (maximum depth $=8 \mathrm{~cm}$ ) sampled in 2017 (deepest core) and 2018 (other cores); purple area $=$ Mn-rich layer with an increasing thickness with the water depth; green text $=$ diffusion of $\mathrm{Mn}_{\text {diss }}$ from porewaters at $58 \mathrm{~m}$ and $69.5 \mathrm{~m}$; purple text $=$ net accumulation rates into the sediment traps at $20 \mathrm{~m}$ and $60 \mathrm{~m}$ for 2017 and 2010-2017 (right, black); bottom right $=$ net difference between $\mathrm{Mn}$ accumulation at the top of the core sampled in $2010\left(125 \mathrm{~g} \mathrm{~m}^{-2}\right)$ and the total $\mathrm{Mn}$ accumulation in the core sampled in $2017\left(940 \mathrm{~g} \mathrm{~m}^{-2}\right)$. The gap between the sedimentation in the trap and the net sedimentation at the lake bottom is explained by an additional lateral flux of $518 \mathrm{~g} \mathrm{~m}^{-2}$ below the trap. (Color figure online)

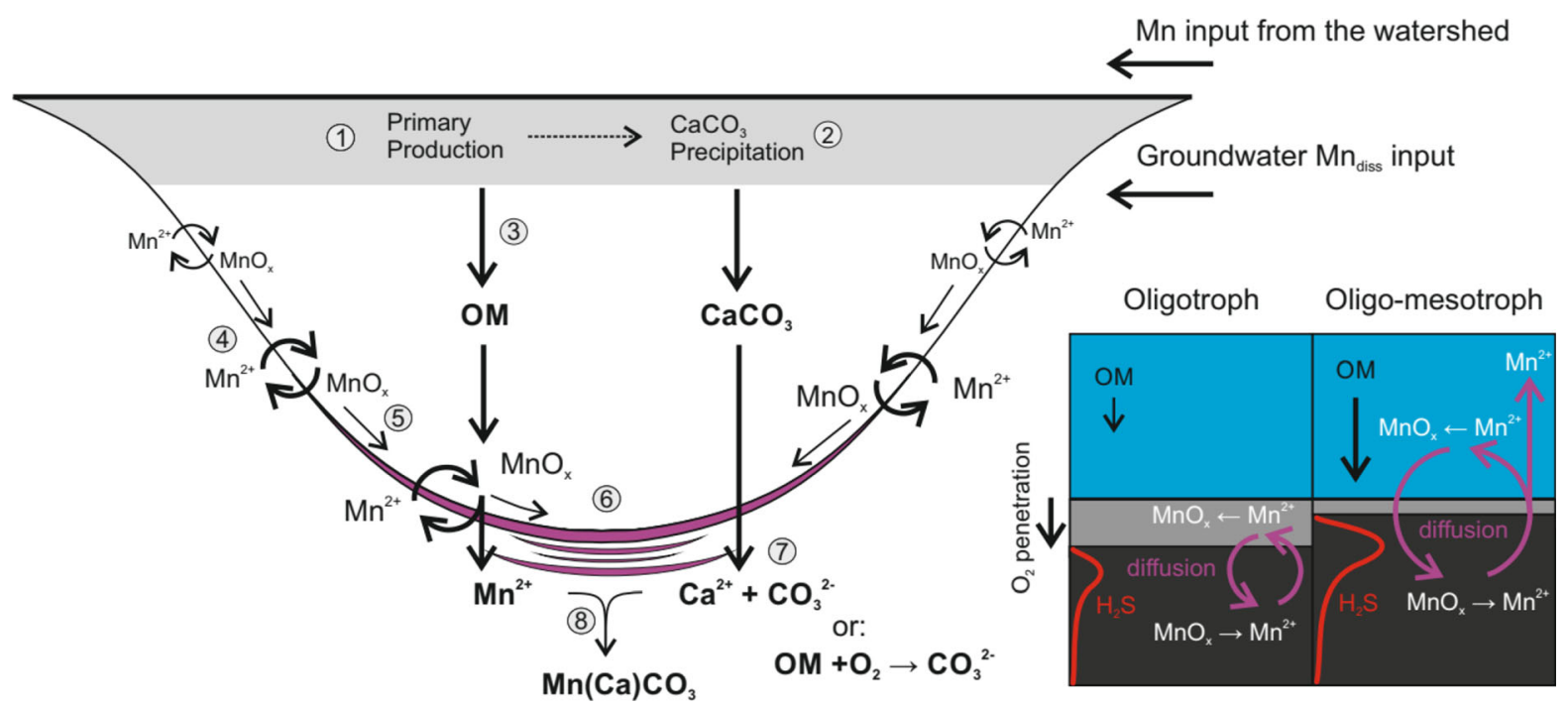

Fig. 13 Left:Conceptual model of geochemical focusing of $\mathrm{Mn}$ and the formation of $\mathrm{Mn}(\mathrm{Ca}) \mathrm{CO}_{3}$ in Lake Stechlin. Numbers 1-8 represent the key processes involved and areexplained in the main text. Purple layers represent buried Mn. Right: Theporewater $\mathrm{Mn}$ flux during the oligotrophic phase was likely essentially lowerdue to a deeper $\mathrm{O}_{2}$ penetration into the sediment and less organicmatter deposition limiting dissimilatory $\mathrm{MnO}_{\mathrm{x}}$ reduction as well asbacterial sulphate reduction finally causing lower $\mathrm{Mn}_{\mathrm{diss}}$ concentrations 
turbulent mixing of dissolved or colloidal Mn throughout the basin. Mass balance calculations showed that $\mathrm{MnO}_{\mathrm{x}}$ is transported through the water column from shallow depths towards the deepest site close to the sediment surface. (6) $\mathrm{MnO}_{\mathrm{x}}$ then accumulates at the deepest point in the lake where, owing to renewed reductive dissolution, porewater $\mathrm{Mn}_{\text {diss }}$ concentrations increase. (7) Simultaneously, carbonate-ions are supplied either by organic matter degradation or calcite dissolution. (8) Finally, $\mathrm{Mn}(\mathrm{Ca}) \mathrm{CO}_{3}$ precipitation is facilitated by high $\mathrm{Mn}_{\text {diss }}$ concentrations potentially supported by bacterial mediation.

In this model, shallow-water sediments act as the source of $\mathrm{Mn}_{\text {diss }}$, whereas sediments in the deepest part of the lake act as a net sink of particulate Mn. Consequently, geochemical focusing is not expected to occur if a geochemically resistant mineral phase is formed (e.g. $\mathrm{Mn}(\mathrm{Ca}) \mathrm{CO}_{3}$ ) at shallower water depths or, more generally, in the source area. As described by Schaller and Wehrli (1996), such geochemical focusing occurs when an anoxic sediment environment is in contact with an oxic water column. Accordingly, the reason why geochemical focusing of $\mathrm{Mn}$ in Lake Stechlin was not active during the pre-eutrophication phase was probably because of dissolved oxygen that could penetrate sufficiently deep into the sediment to prevent substantial $\mathrm{Mn}_{\text {diss }}$ diffusion out of the sediment (Fig. 13). The role of organic matter should be emphasised, as the TOC-rich sediments of Lake Stechlin provide a sharp redox gradient in contact with the (sub-)oxic water column, as evidenced by the sharp gradient of dissolved sulphide concentration just below the SWI (Fig. 7). Quite similar to our findings in Lake Stechlin, $\mathrm{Mn}(\mathrm{Ca}) \mathrm{CO}_{3}$ is found occasionally in organic-rich marine sediments (e.g. Calvert and Pedersen 1996; Häusler et al. 2018).

Previous studies on Mn as a redox-proxy (e.g. Mackereth 1966; Wersin et al. 1991; Naeher et al. 2013) have stated that increasing $\mathrm{Mn} / \mathrm{Fe}$ ratios are indicative of oxic conditions. Our findings show the opposite (Fig. 3), whereby eutrophication and more reducing conditions caused the geochemical focusing and burial of $\mathrm{Mn}$ as $\mathrm{Mn}(\mathrm{Ca}) \mathrm{CO}_{3}$, showing that geochemical focusing may occur during a transition from oligotrophic to mesotrophic conditions. In Lake Stechlin (this study) and Lake Zurich (Naeher et al. 2013), geochemical focusing caused the enrichment of Mn towards the deepest sites, reflected by high $\mathrm{Mn} / \mathrm{Fe}$ ratios in comparison to other sites. However, Mn geochemical focusing began in Lake Zurich during oligotrophication from eutrophic towards mesotrophic conditions (Naeher et al. 2013), whereas in Lake Stechlin, the process was active during eutrophication from oligotrophic towards mesotrophic conditions. During periods with $\mathrm{O}_{2}$-free bottom waters in Lake Zurich between 1940 and 1950 (Naeher et al. 2013), insufficient $\mathrm{Mn}$ availability in the sediments due to reductive dissolution of $\mathrm{MnO}_{\mathrm{x}}$ and coupled $\mathrm{Mn}_{\text {diss }}$ escape into the water column probably inhibited the formation of stable Mn minerals including rhodochrosite. Therefore, we conclude that similar to the Baltic Sea (Häusler et al. 2018) geochemical focusing and $\mathrm{Mn}(\mathrm{Ca}) \mathrm{CO}_{3}$ formation may occur only when bottom waters are replenished with $\mathrm{O}_{2}$ containing waters (e.g. by annual mixing or water inflows), such that $\mathrm{MnO}_{\mathrm{x}}$ can accumulate at the sediment surface and a stable $\mathrm{Mn}$ mineral phase forms during renewed reductive dissolution.

Our measurements of $\mathrm{O}_{2}$ concentrations in the water column suggest that oxic or suboxic-but not sulphidic-conditions occurred throughout the year until approximately 2010. Since then, anoxic (or even sulphidic) bottom waters appeared at the end of the summer stagnation period. However, if climatic warming prolongs the stratification period of Lake Stechlin and, additionally, the ongoing eutrophication results in increasingly $\mathrm{O}_{2}$-depleted bottom waters, the lake may become meromictic so that geochemical focusing and coupled $\mathrm{Mn}(\mathrm{Ca}) \mathrm{CO}_{3}$ formation may become inhibited.

\section{Conclusions}

We have shown that Mn enrichment of Lake Stechlin is linked to a recent period of eutrophication in this once oligotrophic lake. Dissolved Mn originates from shallow and deep sediments and diffuses out of the sediment into the oxic-suboxic water column. Dissolved $\mathrm{Mn}$ is oxidised to $\mathrm{MnO}_{\mathrm{x}}$ particles, transported through the water column close to the sediment surface, and is deposited in the deepest areas of the lake as a part of a varved section. The burial of Mn was enabled by the partial conversion of $\mathrm{MnO}_{\mathrm{x}}$ into Carich rhodochrosites $\left(\mathrm{Mn}(\mathrm{Ca}) \mathrm{CO}_{3}\right)$ shortly after sedimentation. The formation of $\mathrm{Mn}(\mathrm{Ca}) \mathrm{CO}_{3}$ does not occur at the shallower sites, most likely due to the low $\mathrm{Mn}_{\text {diss }}$ concentrations resulting from the low $\mathrm{MnO}_{\mathrm{x}}$ 
content of the sediments. Increased primary production, concomitant with the eutrophication, provides organic matter that intensifies various biogeochemical diagenetic processes upon degradation. Further Mn peaks buried deeper in the sediments at the deepest areas of the lake indicate that the geochemical focusing process has also been active in the past. As such, Mn may be used as a proxy of paleo-redox dynamics. In accordance with the concept of the geochemical focusing and studies from the deep Baltic basins, the redox-driven re-sedimentation of $\mathrm{Mn}$ seems possible only if anoxic sediment is in contact with an $\mathrm{O}_{2}$-containing water column. Our study of Lake Stechlin also shows that oligotrophic lakes that experience eutrophication may be subject to geochemical focusing and parameters including lake morphology (e.g. the relatively small area of the deepest site), organic-rich sediment, and a long water residence time may favour this phenomenon. In comparison to previous research, $\mathrm{Mn} / \mathrm{Fe}$ values were found to function oppositely in our study, and as such, the applicability of this ratio as a redox-proxy requires further assessment.

Acknowledgements We thank Sylvia Jordan, Thomas Gonsiorczyk, Michael Sachtleben, and Kay Simmack for help with fieldwork. Anne Köhler and Sascha Plewe are thanked for support during core scanning, metal analysis, and SEM-EDX. For chemical analyses, we are grateful to Angela Krüger, Elisabeth Schütte, Claudia Schmalsch, Hans-Jürgen Exner, and Grit Siegert. Thomas Mehner and Andreas Kleeberg provided helpful comments on earlier versions of the manuscript as well as the Editage (www.editage.com) for English language editing.

Open Access This article is licensed under a Creative Commons Attribution 4.0 International License, which permits use, sharing, adaptation, distribution and reproduction in any medium or format, as long as you give appropriate credit to the original author(s) and the source, provide a link to the Creative Commons licence, and indicate if changes were made. The images or other third party material in this article are included in the article's Creative Commons licence, unless indicated otherwise in a credit line to the material. If material is not included in the article's Creative Commons licence and your intended use is not permitted by statutory regulation or exceeds the permitted use, you will need to obtain permission directly from the copyright holder. To view a copy of this licence, visit http://creativecommons.org/licenses/by/4.0/.

Funding This study is part of the "BaltRap" project (The Baltic Sea and its Southern Lowlands: Proxy-Environment interactions in times of rapid changes) funded by the Leibniz
Association (SAW-2017-IOW-2998). Open Access funding enabled and organized by Projekt DEAL.

\section{References}

Aguilar C, Nealson KH (1998) Biogeochemical cycling of manganese in Oneida Lake, New York: whole Lake studies of manganese. J Great Lakes Res 24:93-104. https://doi. org/10.1016/S0380-1330(98)70802-0

Aller RC, Rude PD (1988) Complete oxidation of solid phase sulfides by manganese and bacteria in anoxic marine sediments. Geochim Cosmochim Acta 52:751-765. https:// doi.org/10.1016/0016-7037(88)90335-3

Berner RA, Scott MR, Thomlinson C (1970) Carbonate alkalinity in the pore waters of anoxic marine sediments. Limnol Oceanogr 15:544-549. https://doi.org/10.4319/lo. 1970.15.4.0544

Boudreau BP (1996) The diffusive tortuosity of fine-grained unlithified sediments. Geochim Cosmochim Acta 60:3139-3142. 7037(96)00158-5

Burdige DJ (1993) The biogeochemistry of manganese and iron reduction in marine sediments. Earth-Sci Rev 35:249-284. https://doi.org/10.1016/0012-8252(93)90040-E

Calvert SE, Pedersen TF (1993) Geochemistry of Recent oxic and anoxic marine sediments: Implications for the geological record. Mar Geol 113:67-88. https://doi.org/10. 1016/0025-3227(93)90150-T

Calvert SE, Pedersen TF (1996) Sedimentary geochemistry of manganese: implications for the environment of formation of manganiferous black shales. Econ Geol 91:36-47. https://doi.org/10.2113/gsecongeo.91.1.36

Casper P (1994) Die Cäsium-Datierung von Sedimenten unterschiedlicher mikrobieller Aktivität. Deutsche Gesellschaft für Limnologie, Jahrestagung, Hamburg, pp 386-389

Casper P, Bianchi M, Muntau H (1995) Spatial and temporal variations of heavy metals in the sediments of Lake Stechlin (Germany). Limnologica 25:301-309

Cline JD (1969) Spectrophotometric determination of sulfide in water. Limnol Oceanogr 14:454-458. https://doi.org/10. 4319/lo.1969.14.3.0454

Croudace IW, Rindby A, Rothwell RG (2006) ITRAX: description and evaluation of a new multi-function X-ray core scanner. Geol Soc Spec Publ 267:51-63. https://doi. org/10.1144/GSL.SP.2006.267.01.04

Davison W (1993) Iron and manganese in lakes. Earth Sci Rev 34:119-163. https://doi.org/10.1016/00128252(93)90029-7

Davison W, Woof C (1984) A study of the cycling of manganese and other elements in a seasonally anoxic lake. Rostherne Mere UK Water Res 18:727-734. https://doi.org/10.1016/ 0043-1354(84)90168-4

Delfino JJ, Bortleson GC, Lee GF (1969) Distribution of Mn, Fe, $\mathrm{Mg} \mathrm{P}, \mathrm{K}, \mathrm{Na}$, and $\mathrm{Ca}$ in the surface sediments of Lake Mendota, Wisconsin. Environ Sci Technol 3:1189-1192. https://doi.org/10.1021/es60034a006

Delfino JJ, Lee GF (1971) Variation of manganese, dissolved oxygen and related chemical parameters in the bottom 
waters of Lake Mendota, Wisconsin. Water Res 5:1207-1217. https://doi.org/10.1016/00431354(71)90085-6

Dellwig O, Leipe T, März C, Glockzin M, Pollehne F, Schnetger B. Yakushev EV, Böttcher ME, Brumsack H-J (2010) A new particulate $\mathrm{Mn}-\mathrm{Fe}-\mathrm{P}$-shuttle at the redoxcline of anoxic basins. Geochim Cosmochim Acta 74:7100-7115. https://doi.org/10.1016/j.gca.2010.09.017

Dellwig O, Schnetger B, Brumsack H-J, Grossart H-P, Umlauf L (2012) Dissolved reactive manganese at pelagic redoxclines (part II): hydrodynamic conditions for accumulation. J Mar Syst 90:31-41. https://doi.org/10.1016/j.jmarsys. 2011.08.007

Dellwig O, Schnetger B, Meyer D, Pollehne F, Häusler K, Arz HW (2018) Impact of the major Baltic inflow in 2014 on manganese cycling in the gotland deep (Baltic Sea). Front Mar Sci 5:1-20. https://doi.org/10.3389/fmars.2018.00248

Dellwig O, Wegwerth A, Schnetger B, Schulz H, Arz HW (2019) Dissimilar behaviors of the geochemical twins W and Mo in hypoxic-euxinic marine basins. Earth Sci Rev 193:1-23. https://doi.org/10.1016/j.earscirev.2019.03.017

Dräger N, Theuerkauf M, Szeroczyńska K, Wulf S, Tjallingii R, Plessen B, Kienel U, Brauer A (2017) Varve microfacies and varve preservation record of climate change and human impact for the last 6000 years at Lake Tiefer See (NE Germany). Holocene 27:450-464. https://doi.org/10. $1177 / 0959683616660173$

Friedl G, Wehrli B, Manceau A (1997) Solid phases in the cycling of manganese in eutrophic lakes: new insights from EXAFS spectroscopy. Geochim Cosmochim Acta 61:275-290. 7037(96)00316-X

Giblin AE (2009) Iron and manganese. In: Likens GE (ed) Encyclopedia of inland waters. Academic Press, Oxford, pp 35-44. https://doi.org/10.1016/B978-012370626-3. 00096-X

Gonsiorczyk T, Casper P, Koschel R (1995) Comparative sediment investigations of the carbon and phosphorus content in Baltic Lakes. Limnologica 25:365-379

Granina L, Müller B, Wehrli B (2004) Origin and dynamics of $\mathrm{Fe}$ and $\mathrm{Mn}$ sedimentary layers in Lake Baikal. Chem Geol 205:55-72. https://doi.org/10.1016/j.chemgeo.2003.12. 018

Hamilton-Taylor J, Price NB (1983) The geochemistry of iron and manganese in the waters and sediments of Bolstadfjord, S.W. Norway. Estuar Coast Shelf Sci 17:1-19. https://doi.org/10.1016/0272-7714(83)90041-0

Hamilton-Taylor J, Davison W, Morfett K (1996) The biogeochemical cycling of $\mathrm{Zn}, \mathrm{Cu}, \mathrm{Fe}, \mathrm{Mn}$, and dissolved organic $\mathrm{C}$ in a seasonally anoxic lake. Limnol Oceanogr 41:408-418. https://doi.org/10.4319/1o.1996.41.3.0408

Häusler K, Dellwig O, Schnetger B, Feldens P, Leipe T, Moros M, Pollehne F, Schönke M, Wegwerth A, Arz HW (2018) Massive Mn carbonate formation in the Landsort deep (Baltic Sea): hydrographic prerequisites, temporal succession and $\mathrm{Mn}$ budget calculations. Mar Geol 395:260-270. https://doi.org/10.1016/j.margeo.2017.10. 010

Henkel JV, Dellwig O, Pollehne F, Herlemann DPR, Leipe T, Schulz-Vogt HN (2019) A bacterial isolate from the Black Sea oxidizes sulfide with manganese(IV) oxide. Proc Natl
Acad Sci USA 116:12153-12155. https://doi.org/10.1073/ pnas. 1906000116

Herndon EM, Havig JR, Singer DM, McCormick ML, Kump LR (2018) Manganese and iron geochemistry in sediments underlying the redox-stratified Fayetteville Green Lake. Geochim Cosmochim Acta 231:50-63. https://doi.org/10. 1016/j.gca.2018.04.013

Hesslein RH (1976) An in-situ sampler for close interval pore water studies. Limnol Oceanogr 21:912-914. https://doi. org/10.4319/lo.1976.21.6.0912

Huckriede H, Meischner D (1996) Origin and environment of manganese-rich sediments within black-shale basins. Geochim Cosmochim Acta 60:1399-1413. https://doi.org/ 10.1016/0016-7037(96)00008-7

Jarvis S, Croudace IW, Rothwell RG (2015) Parameter optimisation for the ITRAX Core Scanner. In: Croudace IW, Rothwell RG (eds) Micro-XRF studies of sediment cores. Springer, Dordrecht, pp 535-562. https://doi.org/10.1007/ 978-94-017-9849-5_22

Johnson JE, Webb SM, Ma C, Fischer WW (2016) Manganese mineralogy and diagenesis in the sedimentary rock record. Geochim Cosmochim Acta 173:210-231. https://doi.org/ 10.1016/j.gca.2015.10.027

Kirillin G, Shatwell T, Kasprzak P (2013) Consequences of thermal pollution from a nuclear plant on lake temperature and mixing regime. J Hydrol 496:47-56. https://doi.org/10. 1016/j.jhydrol.2013.05.023

Kleeberg A (2014) Ursachen einer periodischen ManganAkkumulation in Sedimenten. Deutsche Gesellschaft für Limnologie, Erweiterte Zusammenfassungen der Jahrestagung 2013 (Potsdam-Berlin), Hardegsen, pp 105-109

Koschel R, Adams DD (2003) An approach to understanding a temperate oligotrophic lowland lake (Lake Stechlin, Germany). Arch Hydrobiol Spec Issues Advanc Limnol 58:1-9

Koschel R, Mothes G, Casper SJ (1985) The ecosystem Lake Stechlin. The life of the lake. In: Casper SJ (ed) Lake Stechlin. Monographiae Biologicae, 58. Springer, Dordrecht, pp 411-435. https://doi.org/10.1007/978-94-0095506-6_15

Krey L (1985) The lakes of the Lake Stechlin area: aspects of their morphometry. In: Casper SJ (ed) Lake Stechlin. Monographiae Biologicae, vol 58. Springer, Dordrecht, pp 29-40. https://doi.org/10.1007/978-94-009-5506-6_2

Lee C, Hedges JI, Wakeham S, Zhu N (1992) Effectiveness of various treatments in retarding microbial activity in sediment trap material and their effects on the collection of swimmers. Limnol Oceanogr 37:117-130. https://doi.org/ 10.4319/lo.1992.37.1.0117

Lee JH, Kennedy DW, Dohnalkova A, Moore DA, Nachimuthu P, Reed SB, Fredrickson JK (2011) Manganese sulfide formation via concomitant microbial manganese oxide and thiosulfate reduction. Environ Microbiol 13:3275-3288. https://doi.org/10.1111/j.1462-2920.2011.02587.x

Lenz C, Jilbert T, Conley DJ, Wolthers M, Slomp CP (2015a) Are recent changes in sediment manganese sequestration in the euxinic basins of the Baltic Sea linked to the expansion of hypoxia? Biogeosciences 12:4875-4894. https://doi. org/10.5194/bg-12-4875-2015

Lenz C, Jilbert T, Conley DJ, Slomp CP (2015b) Hypoxia-driven variations in iron and manganese shuttling in the Baltic 
Sea over the past 8 kyr. Geochem Geophys Geosyst 16:3754-3766. https://doi.org/10.1002/2015GC005960

Lepland A, Stevens RL (1998) Manganese authigenesis in the Landsort Deep, Baltic Sea. Mar Geol 151:1-25. https://doi. org/10.1016/S0025-3227(98)00046-2

Lewandowski J, Schauser I, Hupfer M (2002) Die Bedeutung von Sedimentuntersuchungen bei der Auswahl geeigneter Sanierungs- und Restaurierungsmaßnahmen. Hydrol Wasserbewirtsch 46:2-13

Li Y-H, Gregory S (1974) Diffusion of ions in sea water and in deep sea sediments. Geochim Cosmochim Acta 38:703-714. https://doi.org/10.1016/00167037(74)90145-8

Lungfiel T (2018) Räumliche Sedimentanalyse zur Erfassung der Phosphorbindungsformen und Diffusion von gelöstem Phosphor in den Wasserkörper - Konsequenzen für den pelagischen P - Haushalt des Stechlinsees. Bachelor thesis, Technical University of Berlin, Berlin, Germany

Lyons TW, Severmann S (2006) A critical look at iron paleoredox proxies: new insights from modern euxinic marine basins. Geochim Cosmochim Acta 70:5698-5722. https:// doi.org/10.1016/j.gca.2006.08.021

Mackereth FJH (1966) Some chemical observations on postglacial lake sediments. Philos Trans R Soc Lond Ser B Biol Sci 250:165-213. https://doi.org/10.1098/rstb.1966.0001

Madison AS, Tebo BM, Mucci A, Sundby B, Luther GW (2013) Abundant porewater $\mathrm{Mn}(\mathrm{III})$ is a major component of the sedimentary redox system. Science 341:875-878. https:// doi.org/10.1126/science. 1241396

Mayer LM, Liotta FP, Norton SA (1982) Hypolimnetic redox and phosphorus cycling in hypereutrophic Lake Sebasticook, Maine. Water Res 16:1189-1196. https://doi.org/10. 1016/0043-1354(82)90137-3

Middelburg JJ, De Lange GJ, van Der Weijden CH (1987) Manganese solubility control in marine pore waters. Geochim Cosmochim Acta 51:759-763. https://doi.org/10. 1016/0016-7037(87)90086-X

Moller T, Schulz H, Hamann Y, Dellwig O, Kucera M (2012) Sedimentology and geochemistry of an exceptionally preserved last interglacial sapropel S5 in the Levantine Basin (Mediterranean Sea). Mar Geol 291-294:34-48. https:// doi.org/10.1016/j.margeo.2011.10.011

Naeher S, Gilli A, North RP, Hamann Y, Schubert CJ (2013) Tracing bottom water oxygenation with sedimentary $\mathrm{Mn} /$ $\mathrm{Fe}$ ratios in Lake Zurich, Switzerland. Chem Geol 352:125-133. https://doi.org/10.1016/j.chemgeo.2013.06. 006

Neumann T, Heiser U, Leosson MA, Kersten M (2002) Early diagenetic processes during Mn-carbonate formation: evidence from the isotopic composition of authigenic $\mathrm{Ca}$ rhodochrosites of the Baltic Sea. Geochim Cosmochim Acta 66:867-879. https://doi.org/10.1016/S00167037(01)00819-5

Nuhfer EB, Anderson RY, Bradbury JP, Dean WE (1993) Modern sedimentation in Elk Lake, Clearwater County, Minnesota. Spec Pap Geol Soc Am 276:75-96. https://doi. org/10.1130/SPE276-p75

Och LM, Müller B, Voegelin A, Ulrich A, Göttlicher J, Steiniger R, Mangold S, Vologina EG, Sturm M (2012) New insights into the formation and burial of $\mathrm{Fe} / \mathrm{Mn}$-accumulations in
Lake Baikal sediments. Chem Geol 330-331:244-259. https://doi.org/10.1016/j.chemgeo.2012.09.011

Oldham VE, Mucci A, Tebo BM, Luther GW (2017) Soluble $\mathrm{Mn}(\mathrm{III})-\mathrm{L}$ complexes are abundant in oxygenated waters and stabilised by humic ligands. Geochim Cosmochim Acta 199:238-246. https://doi.org/10.1016/j.gca.2016.11. 043

Ostendorp W, Frevert T (1979) Untersuchungen zur Manganfreisetzung und zum Mangangehalt der Sedimentoberschicht im Bodensee. Arch Hydrobiol 55:255-277

Pedersen TF, Price NB (1982) The geochemistry of manganese carbonate in Panama Basin sediments. Geochim Cosmochim Acta 46:59-68. https://doi.org/10.1016/00167037(82)90290-3

Pöschke F, Nützmann G, Engesgaard P, Lewandowski J (2018) How does the groundwater influence the water balance of a lowland lake? A field study from Lake Stechlin, northeastern Germany. Limnologica 68:17-25. https://doi.org/ 10.1016/j.limno.2017.11.005

Psenner R, Pucsko R, Sager M (1984) Fractionation of organic and inorganic phosphorus compounds in lake sediments. An attempt to characterize ecologically important fractions. Arch Hydrobiol 70:111-155

Rajendran A, Kumara MD, Bakker JF (1992) Control of manganese and iron in Skagerrak sediments (northeastern North Sea). Chem Geol 98:111-129. https://doi.org/10. 1016/0009-2541(92)90094-L

Richter D, Koschel R (1985) The hydrometeorology of the Lake Stechlin area. In: Casper SJ (ed) Lake Stechlin. Monographiae Biologicae, vol 58. Springer, Dordrecht, pp 41-86. https://doi.org/10.1007/978-94-009-5506-6_3

Roeser P, Franz SO, Litt T (2016) Aragonite and calcite preservation in sediments from Lake Iznik related to bottom lake oxygenation and water column depth. Sedimentology 63:2253-2277. https://doi.org/10.1111/sed.12306

Röper H-P, Schwarz S (2003) Late Pleistocene and Holocene sediment characteristics of Lake Stechlin, with particular reference to manganese enrichment. Arch Hydrobiol Spec Issues Adv Limnol 58:247-279

Schaller T, Wehrli B (1996) Geochemical-focusing of manganese in lake sediments - an indicator of deep-water oxygen conditions. Aquat Geochem 2:359-378. https://doi. org/10.1007/BF00115977

Schnetger B, Dellwig O (2012) Dissolved reactive manganese at pelagic redoxclines (part I): a method for determination based on field experiments. J Mar Syst 90:23-30. https:// doi.org/10.1016/j.jmarsys.2011.08.006

Scholz F, McManus J, Sommer S (2013) The manganese and iron shuttle in a modern euxinic basin and implications for molybdenum cycling at euxinic ocean margins. Chem Geol 355:56-68. https://doi.org/10.1016/j.chemgeo.2013.07. 006

Selmeczy GB, Abonyi A, Krienitz L, Kasprzak P, Casper P, Teles A, Somogyvári Z, Padisák J (2019) Old sins have long shadows: climate change weakens efficiency of trophic coupling of phyto- and zooplankton in a deep oligomesotrophic lowland lake (Stechlin, Germany)-a causality analysis. Hydrobiologia 831:101-117. https:// doi.org/10.1007/s10750-018-3793-7

Stauffer RE (1987) A comparative analysis of iron, manganese, silica, phosphorus, and sulfur in the hypolimnia of 
calcareous lakes. Water Res 21:1009-1022. https://doi.org/ 10.1016/0043-1354(87)90022-4

Stevens LR, Ito E, Olson DEL (2000) Relationship of Mn-carbonates in varved lake sediments to catchment vegetation in Big Watab Lake, MN, USA. J Paleolimnol 24:199-211. https://doi.org/10.1023/A:1008169526577

Suess E (1979) Mineral phases formed in anoxic sediments by microbial decomposition of organic matter. Geochim Cosmochim Acta 43:339-352. https://doi.org/10.1016/ 0016-7037(79)90199-6

Tebo BM, Bargar JR, Clement BG, Dick GJ, Murray KJ, Parker D, Verity R, Webb SM (2004) Biogenic manganese oxides: properties and mechanisms of formation. Annu Rev Earth Planet Sci 32:287-328. https://doi.org/10.1146/annurev. earth.32.101802.120213

Tribovillard N, Algeo TJ, Lyons T, Riboulleau A (2006) Trace metals as paleoredox and paleoproductivity proxies: an update. Chem Geol 232:12-32. https://doi.org/10.1016/j. chemgeo.2006.02.012

Trouwborst RE, Clement BG, Tebo BM, Glazer BT, Luther GW (2006) Soluble $\mathrm{Mn}(\mathrm{III})$ in suboxic zones. Science 313:1955-1957. https://doi.org/10.1126/science.1132876
Wersin P, Höhener P, Giovanoli R, Stumm W (1991) Early diagenetic influences on iron transformations in a freshwater lake sediment. Chem Geol 90:233-252. https://doi. org/10.1016/0009-2541(91)90102-W

Wittkop C, Swanner ED, Grengs A, Lambrecht N, Fakhraee M, Myrbo A, Bray AW, Poulton SW, Katsev S (2020) Evaluating a primary carbonate pathway for manganese enrichments in reducing environments. Earth Planet Sci Lett 538:116201. https://doi.org/10.1016/j.epsl.2020. 116201

Yao W, Millero FJ (1993) The rate of sulfide oxidation by $\delta \mathrm{MnO}_{2}$ in seawater. Geochim Cosmochim Acta 57:3359-3365. 7037(93)90544-7

Publisher's Note Springer Nature remains neutral with regard to jurisdictional claims in published maps and institutional affiliations. 